\title{
Evolutionary Economics, Responsible Innovation and Demand: Making a Case for the Role of Consumers
}

\author{
Michael P. Schlaile ${ }^{1,2} \cdot$ Matthias Mueller ${ }^{2}$. \\ Michael Schramm ${ }^{1}$ - Andreas Pyka ${ }^{2}$
}

Published online: 10 February 2017

C The Author(s) 2017. This article is published with open access at Springerlink.com

\begin{abstract}
This paper contributes to the (re-)conceptualisation of responsible innovation by proposing an evolutionary economic approach that focuses on the role of consumers in the innovation process. After a discussion of the philosophical foundations and ethical implications of this approach, which bears an explanatory potential that has not been adequately considered in previous discussions of responsible innovation, we present a first step towards capturing the important but often neglected role of consumers in innovation processes (including responsible innovation): We propose an agent-based model that incorporates a multidimensional space of characteristics in which new products or services are represented by more than the mere aspect of price and quality. Instead, innovations are denoted by a large set of characteristics, including also negative or harmful ones. The model is used to illustrate that consumers' heterogeneity and bounded rationality - even if considered in a simple manner - indeed play a crucial role in the creation and diffusion of responsible innovation which can and should be used for further work in this field and for possible extensions of the model.
\end{abstract}

Keywords Agent-based modelling - Consumer social responsibility - Evolutionary economics · Innovation and demand $\cdot \mathrm{Neo}-\mathrm{Sch}$ umpeterian economics $\cdot$ Responsible innovation $\cdot$ Shared responsibility

Michael P. Schlaile

schlaile@uni-hohenheim.de

1 Department of Business Ethics (560 D), University of Hohenheim, Wollgrasweg 23, 70599 Stuttgart, Germany

2 Department of Innovation Economics (520i), University of Hohenheim, Wollgrasweg 23, 70599 Stuttgart, Germany 


\section{Introduction}

Vincent Blok and Pieter Lemmens (2015) have rightly observed that the current view of innovation in the responsible innovation literature often appears to be narrow. It is, therefore, justified to call for research on responsible innovation that more adequately takes into account that innovation is an endogenous process emerging from the (inter)actions of interdependent heterogeneous agents in a complex system, where the outcomes are often characterised by fundamental uncertainty (see also Pyka 2014). Moreover, what Blok and Lemmens (2015) aim to criticise as an "economic" perspective seems closely related to what Jerry Courvisanos (2007, p. 42) has called the "inadequate orthodox ontology of innovation". Traditional methods of mainstream economics (e.g. approaches involving the solution of well-defined optimisation problems by rational representative agents; such as profit and utility maximisation) are rather futile when it comes to understanding and explaining innovation in general (Pyka 2014; Vermeulen and Pyka 2016) and responsible innovation in particular. By its very nature, responsible innovation represents a wicked problem (e.g. Blok and Lemmens 2015; Flipse et al. 2014; Pavie and Carthy 2014), requiring more suitable (economic) approaches. As Horst Rittel and Melvin Webber, who coined the notion of wicked problems, already explained nearly half a century ago:

"[I]n a pluralistic society there is nothing like the undisputable public good; there is no objective definition of equity; policies that respond to social problems cannot be meaningfully correct or false; and it makes no sense to talk about 'optimal solutions' to social problems ..." (Rittel and Webber 1973, p. 155). ${ }^{1}$

In our opinion, there already exist more appropriate concepts and methods that have been developed outside the economic mainstream, such as evolutionary or neo-Schumpeterian economics (e.g. Dopfer 2001, 2005, 2016; Hanusch and Pyka 2007a; Herrmann-Pillath 2013; Magnusson 1994; Witt 2003, 2008, 2014) and complexity economics (e.g. Arthur 2015; Beinhocker 2006; Wilson and Kirman 2016). One of the key characteristics of all these approaches is that they attribute a central role to the actors within a dynamic framework of innovation processes (see also Fagerberg et al. 2005, 2013). ${ }^{2}$ In other words, they aim to capture and take into account what Owen et al. (2013) have described in the following way:

"Innovation is not a simple, linear model with clear lines of sight from invention to impact, and where accountability for such impacts can be traced. It is an undulating path, sometimes with dead ends, involving many, often loosely-connected actors. It is a complex, collective, and dynamic phenomenon" (Owen et al. 2013, p. 33, italics in original).

In our paper, we follow this notion and claim that the explanatory power of 'heterodox' economic approaches - especially evolutionary economics - is to be exploited much more in discussions about responsible innovation. However, as our paper aims to contribute to the conceptual evolution of responsible innovation, we do not want to confine ourselves at this point to any narrow definitions or particular (normative or political) directions of responsible

\footnotetext{
${ }^{1}$ See also Conklin (2006) for a generalization (and re-definition) of the characteristics of wicked problems.

${ }^{2}$ Cf. Allen $(1988,2015)$ for some examples of how the ideas of complexity, evolutionary processes, uncertainty and innovation intertwine. For insightful reviews of the literature, particularly with regard to (the ontology of) complexity and evolutionary economics, we also refer the reader to Robert and Yoguel $(2015,2016)$.
} 
innovation proposed by other authors in this domain (e.g. Owen et al. 2013; Stahl 2013; Stahl et al. 2013; Stilgoe et al. 2013; von Schomberg 2013; see also Koops 2015; Pellé and Reber 2013, for an overview). As Bert-Jaap Koops writes:

"Although 'responsible innovation' is a term that is increasingly used both in academic and in policy circles, it is by no means clear what exactly the term refers to, nor how responsible innovation, once we know what is meant by this, can or should be approached" (Koops 2015, p. 2).

Consequently, for the purpose of our paper, we understand responsible innovation as a research field under development that aims at making innovation processes as well as the outcomes of these processes (in terms of products, effects, or consequences) more responsible. This seemingly vague "definition" is deemed necessary at this stage due to unresolved issues and terminological ambiguities of both responsibility and innovation in the responsible innovation literature, some of which will be addressed within the course of our paper.

Admittedly, also the evolutionary economic approach is far from being perfectly developed. On the one hand, it requires new methods to generate insights and capture complexity; on the other hand, evolutionary economics often focuses on knowledge and its generation, which is also influenced by ethical considerations and economic actors other than firms. Nevertheless, evolutionary economists have thus far neglected some important ethical aspects as well as the relevance of the so-called demand side (i.e. the role of demanding consumers) in favour of the supply side. Although various innovation scholars have started to increasingly focus on the importance of the demand side (see also Fontana and Guerzoni 2008; Guerzoni 2010), for example, as a determinant for the diffusion of innovations (e.g. Rogers 2003), in terms of public procurement (Edler and Georghiou 2007), as a source of knowledge and creativity (von Hippel 2005) and, more recently, even within evolutionary economic models of demand and innovation (Mueller et al. 2015; Saviotti and Pyka 2012; Valente 2012), the role of consumers still remains somewhat under-represented in evolutionary economics. On top of this, as research on responsible innovation also deals with responsibilities of actors and stakeholders involved in and affected by the complex, collective and dynamic phenomenon of innovation, the importance of the demand side also requires researchers to incorporate recent works on consumer social responsibility (e.g. Schlaile et al. 2016; Schmidt 2016; Vitell 2015).

Building on this, our paper aims to contribute to these discussions in (at least) two ways. First, we make a (philosophically grounded) case for an evolutionary perspective on (responsible) innovation. Second, we present arguments for taking into account neglected ethical aspects as well as the role of consumers in the creation and diffusion of responsible innovations. Finally, we use an agent-based model to demonstrate the versatile consequences if we abandon the limiting and narrow framework of orthodox economics in favour of more realistic models of (responsible) innovation which consider the heterogeneity and bounded rationality of economic actors.

The paper is structured as follows: In order to adequately address these aims, the next section starts with the discussion why we need alternative perspectives to study innovation processes in general and responsible innovation in particular. The subsequent section addresses important but often neglected ethical issues and implications for responsible innovation research. In the 'synthesis' section, we support our claims by presenting an agentbased simulation model of heterogeneous consumers and their impact on responsible innovations. The final section concludes this paper and discusses limitations as well as potentials for further work. 


\section{Why We Need Alternative Perspectives: Philosophical Foundations}

As already noted in the introduction, one can criticise that the responsible innovation literature often seems to view innovations from an "economic perspective" or an "economic paradigm", which sometimes appears to be reduced to the elements of profit (and self-interest), technological innovation and economic growth (e.g. Blok and Lemmens 2015). ${ }^{3}$ Although we agree that future research on responsible innovation should avoid narrow and naïve concepts of innovation, we could also argue that what Blok and Lemmens (2015) call an "economic perspective" does not really do justice to the full spectrum of research on the economics of innovation. In other words, we may have to be more precise with regard to the question of which particular economic paradigm may or may not be suitable for studying responsible innovation.

The following two subsections give a brief philosophically informed overview of two important strands of economic theory, namely the neoclassical and the evolutionary paradigm. Hereby, we aim to emphasise the key characteristics of each approach with an eye towards their implications for addressing (responsible) innovation.

\section{Neoclassical Economics}

Currently, in so-called mainstream economics, the neoclassical school of thought is the dominant paradigm (see also Dobusch and Kapeller 2009; Keen 2011, for further insights). As is generally known, classical mechanics of Newtonian physics has been the inspiring model for neoclassical economics. William Stanley Jevons, for example, explicitly declared: "The Theory of Economy thus treated presents a close analogy to the science of Statical Mechanics" (Jevons, 1871/1957, p. vii). Similarly, Léon Walras wrote: "The pure theory of economics is a science which resembles the physico-mathematical sciences in every respect" (Walras 1874, p. 71). And Vilfredo Pareto proclaimed that "[t]he theory of economic science thus acquires the rigor of rational mechanics" (Pareto 1971, p. 113). By adopting "the general principles of mechanics" (Jevons 1871/1957, p. xvii), neoclassical economists imported a fundamental pattern of thinking, which can be called 'metaphysical'. The term metaphysical labels an allinclusive view of 'how the world works in general', a basic view behind the highly differentiated sciences, which in turn deal with the distinct questions of 'how the world works in detail' (see also Schramm 2016, 2017, on a related note).

In the case of Newtonian classical mechanics and neoclassical economics, the metaphysical paradigm of (mechanistic) machine was adopted. This paradigm has influenced the concepts of the agents, the whole system and the economic methodology (see also Chap. 2 in Dierksmeier 2016). The presupposed model of a representative individual agent (i.e. methodological individualism) within neoclassical economics was the 'homo economicus' who was modelled as a perfectly rational calculating machine, which is just a subjective paraphrase for the presupposed objective mechanics (e.g. Graupe 2012; Hodgson 1998, on a related note). One reason for this was to guarantee - in principle - an analytical solvability or tractability required by the methods of that time (see also Farmer and Foley 2009). Interestingly, the self-interest of

\footnotetext{
${ }^{3}$ Note that the (often implicitly) underlying idea that societal problems may be solved by means of a (profitable) business approach (or that they actually represent a business opportunity) can also be found in other approaches, including social entrepreneurship (see also Schlaile and Ehrenberger 2016, on a related note).
} 
homo economicus was understood as the equivalent to Newton's gravitational force: "Utility only exists when there is on the one side the person wanting and on the other the thing wanted. ... Just as the gravitating force ... utility is an attraction" (Jevons 1981, p. 80). ${ }^{4}$ Self-interest is modelled as a force of attraction in a mechanical system in order to make the overall system predictable: "[T] he theory here given may be described as the mechanics of utility and selfinterest" (Jevons 1871/1957, p. 21, italics in original). This mechanistic model entails at least two problems: First, "the mechanics of utility and self-interest" dismiss the possibility of an individual's moral interests as 'irrational' (cf. below: Sen's critique of "rational fools"). Second, whereas this mechanistic concept of the individual agent survived in economic textbooks up to this day, neoclassical economics neither developed an adequate idea of collective agents nor of the possibility of moral interests of an organisation: Even within the contemporary neoclassical 'theory of the firm' we are told that "organizations are simply legal fictions" (Jensen and Meckling 1976, p. 310, italics in original), which serve "as a focus for a complex process in which the conflicting objectives of individuals ... are brought into equilibrium within a framework of contractual relations" (Jensen and Meckling 1976, p. 311; see also Schramm 2016, 2017, on related discussions).

Speaking of equilibrium, neoclassical economics assumes - again following Newtonian mechanics - that the whole economic system 'naturally' tends towards a definite equilibrium. As a result, innovations are understood merely as exogenous events or 'shocks' - and thereafter the system again moves towards the equilibrium. However, as, for example, Cristiano Antonelli and Giuseppe Scellato (2008, p. 2) put it: "Innovation is not only the cause of out-of-equilibrium conditions, but also the consequence of out-of-equilibrium".

Hence, neoclassical economics (one may say 'naturally') fails to provide a convincing framework for studying dynamic processes such as innovation due to its mechanistic paradigm and the respective assumptions (see also Courvisanos 2007; Dopfer 2007, 2016; Dopfer and Potts 2008, Chap. 2.2; or Kudic 2015, Chap. 2, for a brief overview). Of course, our critique of neoclassical economics is nothing new, as well as innovation is not new to economics. Various writers since Adam Smith (1776/1952) have investigated different aspects of innovation. However, especially with the so-called marginal revolution (see also Rutherford 2007), economics gained a strong methodological emphasis on rational choice theory, optimisation calculus and equilibrium-related methods such as comparative statics, whereas innovation moved out of its scope.

\section{Evolutionary Economics}

As a direct response to Blok and Lemmens (2015), this subsection now describes some aspects of the so-called evolutionary economic approach as means of choice for the analysis of innovations.

Already during the time neoclassical economists developed their mechanistic framework, Darwin, Einstein and Bohr came along and things again changed dramatically within the natural sciences. Sure, "[t]he age of the machine" (Davies and Gribbin 1992, p. 11) was a success story, especially with regard to the countless innovations in engineering, but the underlying metaphysics of this age, the mechanistic paradigm, has simply turned out to be wrong. Evidently, the universe is not a machine, but radically evolutionary and processual. ${ }^{5}$

\footnotetext{
${ }^{4}$ And the price is the equivalent to the centrifugal force.

${ }^{5}$ See also Bohm (1969) and Plotkin (1987) on the metaphysics of process.
} 
First, a machine neither evolves nor grows. But since Charles Darwin's theory of "natural selection" we do know that the biological world is evolving and constantly producing something new. And since the findings of Georges Lemaitre, Edwin Hubble, Arno Penzias and Robert Woodrow Wilson and their "Big Bang" theory we are faced with a cosmological evolution of a growing universe.

Second, no (traditional) machine is able to change its form. But Albert Einstein's "Theory of Relativity" showed "that space and time are not independent and absolute, as Newton had thought, but are enmeshed and relative" (Greene 2004, p. 9).

Third, a machine is made of solid mechanical components. But quantum physics showed that, in fact, not only does the old "machine" of the universe evolve, but its smallest "components" are actually quantized events (processes) of fluent energy. In short: "[T]here is no machine" (Davies and Gribbin 1992, p. 309). Consequently, a philosophy of events, a "Process Philosophy", such as the "Philosophy of Organism" of Alfred North Whitehead is a much more adequate metaphysical concept than the old machine thinking (see also Dibben 2004, 2009; Macklin et al. 2014; Schramm 2016, 2017, on a related note). ${ }^{6}$

Evolutionary economics (e.g. Dopfer 2001, 2005, 2016; Dopfer and Potts 2008; Hanusch and Pyka 2007a; Herrmann-Pillath 2013; Hodgson and Knudsen 2010; Nelson and Winter 1982; Witt 2003) as well as similar approaches in innovation economics (e.g. Fagerberg et al. 2005, 2013; Hall and Rosenberg 2010; Swann 2009), complexity economics (e.g. Arthur 2015; Beinhocker 2006; Wilson and Kirman 2016) or behavioural economics (e.g. Cartwright 2014; Frantz et al. 2017; Heukelom 2014; Kahneman 2011; Thaler and Sunstein 2008) are in line with that metaphysical paradigm of 'organic' processes which again influences the concepts of the agents, the whole system and the economic methodology (see also Potts 2017, on a related note). Within this new paradigm an individual agent is no longer an abstracted perfectly rational calculating machine, but a concrete human being, which is only boundedly rational (makes mistakes) and has different interests, including moral interests. ${ }^{7}$

It is also important to realise that - in contrast to neoclassical economics which failed to elaborate the very idea of a collective agent - in evolutionary economics collective agents like organisations (e.g. firms) or innovation networks (e.g. Pyka 2002, 2007; Pyka and Scharnhorst 2009; see also Buchmann and Pyka 2012, for an overview on innovation networks) are an essential part of the basic approach and its methodology. Metaphysically, collective agents can be understood as "societies" of micro entities which "cooperate" more closely and, in this, achieve a certain stability of structure and therefore the ability to act collectively. ${ }^{8}$ Organisations - such as business enterprises - or innovation networks can thus be imagined,

\footnotetext{
${ }^{6}$ Whitehead's major work is called "Process and Reality" (Whitehead 1929/1978, emphasis added) and is best known as "Process Philosophy" which is a philosophy of events (also termed "actual occasions"). Whitehead explicitly called his metaphysical concept the "Philosophy of Organism" (e.g. Whitehead 1929/1978, pp. xi, 7, 18 and so on).

${ }^{7}$ Whitehead (1929/1978, p. xii) explicitly declares that his cosmological metaphysics tries "to construct a system of ideas which brings the aesthetic, moral, and religious interests into relation with those concepts of the world which have their origin in natural science."

${ }^{8}$ In Whitehead's cosmological metaphysics the micro entities are "ultimate actual entities which can be dimly discerned in the quanta of energy" (Whitehead 1929/1978, p. 91). But these "final real things of which the world is made up" (Whitehead 1929/1978, p. 18) do have the ability to "cooperate" and therefore to build bigger formations - such as atoms, water drops, ants, stones, trees, people or planets - which Whitehead calls societies: "The real actual things that endure are all societies. They are not actual occasions" (Whitehead 1933/1967, p. 204). "Societies" are, accordingly, complex structures and - given the evolution of a certain structure, e.g. a central nervous system or an organisational hierarchy - have the ability of agency.
} 
metaphysically, as 'societies'. Essentially, research on innovation networks aims to capture this aspect of collective agents, namely that there is not just some isolated inventor, innovator or entrepreneur, but rather that "innovation is a multi-player game" (Bessant 2013, p. 9). In the words of Mihaly Csikszentmihalyi (2014, p. 540): "all of us are involved in the creation of creativity: as appreciators, supporters, consumers, and transmitters of novelty."

In this context, an additional advantage of evolutionary economics over the neoclassical mainstream lies in the fact that the role of the state is not restricted to providing framework conditions and correcting "market failures". Instead, in evolutionary economics, also the actors of the public sector are regarded as an endogenous part of the innovation system or innovation networks, which can even allow for states taking an active role in the creation of innovations and innovative markets (Mazzucato 2013, 2016). ${ }^{9}$

Finally, in evolutionary economics, the whole economic system does not tend towards an equilibrium; on the contrary: the system "naturally" is in disequilibrium. It is a world of evolution, a world of novelties and innovations. ${ }^{10}$ Far from being exogenous "shocks", innovations - for good or for bad - are conceptualised as endogenous; they belong to the nature of actuality, of society, and the economic system and are driven by the actions and interactions of heterogeneous and boundedly rational economic actors. In other words, innovations emerge from (inter)actions of micro entities ("humans") (see also Antonelli and Ferraris 2011, on a related note). ${ }^{11}$

For the purpose of an overview, we summarise some of the important differences between neoclassical economics and evolutionary economics in Table $1 .{ }^{12}$

At this juncture, it should be pointed to the fact that there are, of course, other 'heterodox' economic approaches that are, to some extent, compatible with evolutionary and complexity economics but differ in focus and intellectual history. As, for example, Mark Lavoie writes with an eye to common metaphysical beliefs behind different heterodox economic schools of thought:

“Although Marxians, Institutionalists, Structuralists, Evolutionarists, Socio-economists, the French Circuit and Regulation schools, Sraffians and post-Keynesians may have substantially different opinions on various topics, such as the theory of value or the relevance of long-period analysis, I believe they hold the same metaphysical beliefs,

\footnotetext{
${ }^{9}$ Interested readers may also refer to the comprehensive neo-Schumpeterian approach proposed by Horst Hanusch and Andreas Pyka (2007b, c), where the public sector is one of three (co-evolutionary) pillars of economic development (the other two being industry dynamics and financial markets). However, a more profound discussion of the role(s) of an "entrepreneurial state" (Mazzucato 2013, 2016) in responsible innovation would go beyond the scope of this paper and can, therefore, be seen as a direction for future research.

${ }^{10}$ Whitehead's "Process Philosophy" describes this basic character of the world with the term creativity (which was presumably coined by himself!): “'Creativity' is the universal of universals characterizing ultimate matter of fact. It is that ultimate principle. ... 'Creativity' is the principle of novelty" (1929/1978, p. 21, italics in original). ${ }^{11}$ Note that a first important step in this direction was already made more than three decades ago by replacing the sequential view on innovation processes with a network view in which the different phases of innovation are interlinked and not sequential, and the different actors involved in innovation strongly interact (e.g. Kline 1985; Kline and Rosenberg 1986).

${ }^{12}$ Note, however, that evolutionary economics is not as unified a discipline as this overview may suggest (see also Hodgson 2011, or Witt 2008, 2014, on the fragmentation of evolutionary economics). One could argue, for example, that so-called neo-Schumpeterian economics is a sub-field of evolutionary economics that is especially inspired by the works of Joseph Schumpeter but also drawing upon complexity science, among others. NeoSchumpeterian economics is strongly interested in the supply side of the innovation process, probably due to its Schumpeterian 'heritage'. Moreover, for a similar tabular overview of these different economic perspectives, we refer the reader to Eric Beinhocker's table and article on the evonomics website: https://evonomics.com/the-deepand-profound-changes-in-economics-thinking/.
} 
Table 1 An overview of neoclassical vs. evolutionary economics

\begin{tabular}{|c|c|c|}
\hline & Neoclassical economics & Evolutionary economics \\
\hline $\begin{array}{r}\text { Inspiring } \\
\text { model }\end{array}$ & Classical mechanics of physics & Theory of evolution, modern physics \\
\hline $\begin{array}{l}\text { Metaphysical } \\
\text { paradigm }\end{array}$ & (mechanistic) machines & (organic) processes \\
\hline \multirow{4}{*}{$\begin{array}{l}\text { Individual } \\
\text { agents }\end{array}$} & ‘econs’ (homo economicus) & 'humans' \\
\hline & $\begin{array}{l}\text { Perfectly rational (calculating } \\
\text { machines) }\end{array}$ & Boundedly rational, rely on heuristics or rules of thumb \\
\hline & $\begin{array}{l}\text { Self-interest only (like } \\
\text { gravitation in physics) }\end{array}$ & Different interests (incl. moral interests) \\
\hline & Homogeneous (representative) & Heterogeneous (diverse) \\
\hline $\begin{array}{l}\text { Collective } \\
\text { agents }\end{array}$ & $\begin{array}{l}\text { - (mechanical equilibrium } \\
\text { tendencies only) }\end{array}$ & Firms, innovation networks, ... \\
\hline \multirow{2}{*}{$\begin{array}{l}\text { Systemic } \\
\text { characteris- } \\
\text { tics }\end{array}$} & Tendency to equilibrium & $\begin{array}{l}\text { Evolution (e.g. involving processes of variation, selection and } \\
\text { retention / transmission) }\end{array}$ \\
\hline & Innovation exogenous & $\begin{array}{l}\text { Innovation endogenous (emerges from interactions of micro } \\
\text { entities; agent-based) }\end{array}$ \\
\hline Methodology & $\begin{array}{l}\text { Coherent mathematical } \\
\text { apparatus (e.g. calculus) }\end{array}$ & $\begin{array}{l}\text { Interdisciplinary methods (e.g. from sociology, psychology, } \\
\text { network science, evolutionary biology, nonlinear dynamics } \\
\text { and chaos theory, etc.) }\end{array}$ \\
\hline
\end{tabular}

prior to the elements constituting the hard core of their respective theories" (Lavoie 2014, p. 11).

However, despite this metaphysical compatibility, innovation and dynamic change processes are at the heart of evolutionary economics. Although this does not exclude other heterodox approaches from trying to tackle the wicked problem of responsible innovation, evolutionary economics may be considered to already have 'the right foci', and it has also provided a useful framework for approaching issues concerning sustainable development and ecological innovations (e.g. Beckenbach and Nill 2005; Nill 2009, 2011; Nill and Kemp 2009; van Griethuysen 2002a, b), which can be regarded as topics related to responsible innovation.

\section{Ethical Issues and Implications for Responsible Innovation Research}

In the previous section, we have elaborated on the suitability of a process-philosophical and evolutionary approach to innovations in general. Especially due to the dynamic characteristics of innovation phenomena, modelling and simulation tools provide suitable means for scholarly investigation (e.g. Axelrod 1997; Gilbert 2008; Gilbert and Doran 1994; Pyka and Fagiolo 2007; Wilensky and Rand 2015). ${ }^{13}$ However, this does not mean that the available evolutionary economic models already capture the whole spectrum of societal complexities, especially with regard to ethical issues, or the important role of consumers. This section, therefore, focuses on (a non-exhaustive selection of) pivotal ethical issues and (their) implications for responsible innovation research.

\footnotetext{
${ }^{13}$ For the sake of brevity, we cannot go into epistemological debates about simulation, here. Readers interested in the philosophical questions of how simulations may help to generate or advance knowledge are referred to the discussions in Beisbart (2012), Eason et al. (2007), Klein and Herskovitz (2005), Kleindorfer et al. (1998) and Winsberg (2009).
} 


\section{Moral Interests}

The model of 'econs' (homo economicus) within neoclassical economics was a calculating machine, equipped with self-interest only. It is pretty clear that an 'econ' is a methodological abstraction from real 'humans' (Thaler and Sunstein 2008). In contrast to the neoclassical reductionism, the existence of moral interests is conceptually recognised in philosophy and non-neoclassical economics and empirically stressed in behavioural economics. ${ }^{14}$

A prominent proponent of moral interests in the field of philosophy is Immanuel Kant. He always insisted on the fact that there is a plurality of different interests. According to Kant, an interest is not simply self-interest, but more generally the impact of reason on the human will: "An interest is that by which reason becomes practical, i.e. a cause that determines the will" (Kant 1785/2011, p. 147). Now, different types of interests are at work in the two different areas of human activity which Kant distinguishes: Within the area of instrumental rationality or of hypothetical imperatives, "practical reason" is "administering the interest of the inclinations under the sensible principle of happiness" (Kant 1788/2002, p. 154; emphasis added); selfinterest is being managed by rational prudence. And within the 'world' of morality, within the area of Kant's categorical imperative, the 'moral law' - which consists in the impartial or moral point of view - corresponds to a moral interest: "Since in a morally good will the law itself must be the incentive, moral interest is a pure sense-free interest of practical reason alone" (Kant 1788/2002, p. 103; italics in original). ${ }^{15}$

The existence of moral interests is emphasised in non-neoclassical economics, too. Adam Smith, for example, the pioneer of modern economics, was actually a moral philosopher who regarded his first book - The Theory of Moral Sentiments (Smith 1759/2009) - as his most important one. In fact, as Matthias Hühn and Claus Dierksmeier elucidate, the "standard" view of Smith as "an advocate of a value-free or even value-averse conception of economic transactions" (Hühn and Dierksmeier 2016, p. 119) has to be questioned (see also Chap. 3 in Dierksmeier 2016). Quite contrary to this common reading, they argue that:

"Smith stands for values and virtues, for moral reason and a socially embedded rationality. Instead of reducing the economic agent to but an impersonation of a rational pursuit of self-interest, Smith's view of the individual would be that of a socially minded, politically spirited, and contextually oriented person, constantly judging and being judged from the perspective of an 'impartial spectator'" (Hühn and Dierksmeier 2016, p. 120, with reference to Evensky 2005).

Already four decades ago, the economist and philosopher Amartya Sen took up Kant's idea of moral "duties" - Sen uses the term "commitment" - and Smith's ideas of "sympathy" to criticise the ethical deficiencies or limitations of homo economicus. "If the knowledge of torture of others makes you sick, it is a case of sympathy; if it does not make you feel personally worse off, but you think it is wrong and you are ready to do something to stop it, it is a case of commitment" (Sen 1977, p. 326). ${ }^{16}$ A mechanistic model like that of homo economicus, which rules out things like 'sympathy' and moral 'commitment' for being irrational, reduces humans to one-dimensional 'rational fools':

\footnotetext{
${ }^{14}$ See also Schramm $(2006,2008,2010,2015)$ on related discussions.

${ }^{15}$ See also Kant (1785/2011, p. 31): "All moral interest, so called, consists solely in respect for the law" (italics in original).

${ }^{16}$ For an ethical concept that promotes such social virtues see, for example, MacIntyre (2007).
} 
"The purely economic man is indeed close to being a social moron. Economic theory has been much preoccupied with this rational fool decked in the glory of his one allpurpose preference ordering. To make room for the different concepts related to his behavior we need a more elaborate structure" (Sen 1977, p. 336, italics in original; see also Sen's illustrating story of two boys finding two apples on p. 328).

This implies: what we need is a more pluralistic concept of different or diverse interests. Accordingly, the economist and utilitarian John Harsanyi differentiated between 'personal' and 'moral' interests:

"Thus, each individual has two sets of preferences. One consists of his personal preferences, defined as his actual preferences, which will be typically based mainly on his own personal interests ... The other consists of his moral preferences, defined as his hypothetical preferences that he would entertain if he forced himself to judge the world from a moral, i.e., from an impersonal and impartial, point of view" (Harsanyi 1980, p. IX, italics in original). ${ }^{17}$

Evidence for the empirical existence of moral interests is provided by behavioural economics. Two of the classics in this field are, for example, the 'ultimatum game' and the 'dictator game' (Andersen et al. 2011; Bolton 1991; Güth et al. 1982).

Since moral interests have an impact on the decisions and actions of humans, the implications for responsible innovation research are that, first, moral interests can (and probably should) also play a role in the creation and distribution or diffusion of (responsible) innovations and, second, that not every member of a society has the same kind of (moral) preferences or strength of moral interest (i.e. moral interests and preferences are heterogeneous). ${ }^{18}$ Or, as Blok et al. (2015, p. 147) put it, "stakeholders have different ideas about ... ethical and societal aspects of innovation practices."

\section{The "Faustian Aspect" of Innovations: Mitigating an Optimistic Fallacy}

Another important issue also raised by Blok and Lemmens (2015) is that many innovation scholars and also authors in the responsible innovation community seem to be somewhat biased in terms of viewing innovations as being "inherently good" (Blok and Lemmens 2015). The authors, therefore, call attention to the "Faustian aspect of innovation processes" (ibid., p. 30): With reference to Joseph Schumpeter's notion of creative destruction (Schumpeter 1943), Blok and Lemmens maintain that "the positive impact of responsible innovation ... is therefore accompanied by negative impacts elsewhere" (Blok and Lemmens 2015, p. 30). Luc Soete (2013, p. 134) argues in a similar manner that "[t]he slogan 'innovation is good for you' appears to have been underlying most business and policy analyses" and that innovation can also be a process of "destructive creation" (ibid., italics in original) that is "benefiting a few at the expense of many" (ibid, p. 135).

\footnotetext{
${ }^{17}$ Although Harsanyi assumes two sets of interests, the neoclassical heritage is still alive insofar as he regards the personal preferences as actual but the 'moral preferences' as merely hypothetical.

${ }^{18}$ As already Kenneth Boulding wrote, albeit somewhat intricately: "If we were to map the ethical preference systems of the individuals who comprise mankind, we would not find a uniform distribution but we would find a very sharp clustering into cultures and subcultures with relatively empty spaces between the clusters" (Boulding 1969, p. 5).
} 
An evolutionary perspective may also provide a useful mnemonic in this regard. Schumpeter (1943, p. 83) talks about the "process of industrial mutation" (emphasis added) and Bart Verspagen (2005), among others, also uses this metaphor in an innovation context:

"[I]ncremental innovations are the economic counterpart of biological mutation. Natural selection has its counterpart in economic selection, i.e. markets that decide whether or not certain innovations become successful. Just as in biology, many of the 'mutations' ... are not successful ..." (Verspagen 2005, p. 495).

One may only want to add the emphasis that these "mutations" can also be not helpful and even harmful, not just 'not successful'; and it is easy to imagine a certain analogy between detrimental consequences of innovations and noxious biological mutations. Moreover, it should be kept in mind that due to the often uncertain nature of innovations, some "mutations" may also change from being a helpful (adaptation) to being a harmful (maladaptation) one. This emphasis is necessary because also evolutionary economists appear to have fallen victim to this "optimistic fallacy". As Buenstorf et al. (2013) argue:

"[E]volutionary economics has been somewhat one-sided in its treatment of innovation, with the destructive part of the innovative creation process having received relatively little attention. Adverse effects of innovation are rarely discussed ... Many ... examples could be provided for the tendency to ignore the destructive side of innovation in the thrust of research in evolutionary economics" (Buenstorf et al. 2013, p. 2).

It becomes evident that responsible innovation research can benefit from an evolutionary perspective as much as evolutionary economics can benefit from taking potential 'dark sides' of evolutionary processes - particularly those of technological and economic change - more seriously. ${ }^{19}$

\section{The Neglected Consumers}

With recourse to the above argument that "innovation is a multi-player game" (Bessant 2013, p. 9), it is clear that a focus on firms as "producers" of innovations or, more generally, the socalled supply side will be too narrow. Nevertheless, the role and effects of the demand side in innovation processes have long been neglected by innovation economists (see also Coombs et al. 2001; Mueller et al. 2015; Witt 2001a, b). Already since the 1960s, the innovation literature recognises the distinction between "technology push" and "demand pull" (see also Godin and Lane 2013). However, since then much research has focused almost exclusively on entrepreneurs as the drivers of innovation, whereas only recently the demand side has started to receive increased attention (Andersen 2007). For example, Coombs et al. (2001, p. 1) speculate that "evolutionary economists have somewhat neglected the demand side, possibly because it has been so strongly emphasized in neoclassical economics." Indeed, we may find such emphasis not only in neoclassical writings. As early as 1776, Smith already wrote:

\footnotetext{
${ }^{19}$ Note that this issue is also closely related to the general discussion on teleology in evolutionary processes (see e.g. Chap. 6 in Lange 2012, for an overview) and the common misconception that the survival of the fittest units of selection always means progress, particularly in the context of social and economic evolution (see also Schlaile 2015, on a related note).
} 
"Consumption is the sole end and purpose of all production; and the interest of the producer ought to be attended to only so far as it may be necessary for promoting that of the consumer" (Smith 1776/1952, p. 287).

And another much-cited quote can be found in the work of the Austrian economist Ludwig von Mises:

"The direction of all economic affairs is in the market society a task of the entrepreneurs. Theirs is the control of production. They are at the helm and steer the ship. A superficial observer would believe that they are supreme. But they are not. They are bound to obey unconditionally the captain's orders. The captain is the consumer. Neither the entrepreneurs nor the farmers nor the capitalists determine what has to be produced. The consumers do that" (von Mises 1998, p. 270).

This position has become widely known among economists as consumer sovereignty. On various occasions, the notion has been discussed and also criticised in much detail, and we refer the reader to Penz (1986) for an extensive discussion of "consumer sovereignty and human interests" or Persky (1993) for a historical overview of the concept.

From our previous deliberations, it should go without saying that we do not want to make a general case for this position of consumer sovereignty, as it is rather obvious that it would be as onesided as focusing solely on (entrepreneurial) firms or the supply side. We do, however, argue that consumers are important for innovation in general and for responsible innovation in particular.

René von Schomberg (2013, p. 55) also notes, in a similar vein, that "the success of innovation on the market is unpredictable and reflects a continuous shift of needs and preferences of consumers on the market. Innovation is not fully in the hands of the producers of technology" (emphasis added). Nevertheless, we can observe that also recent publications on responsible innovation often argue from a corporate-centered perspective (e.g. Iatridis and Schroeder 2016). Examples of ways for consumers to take an active role in the innovation process may range from co-creation of value (e.g. Lusch and Vargo 2006; Payne et al. 2008; Senge and Carstedt 2001) and co-production (see also Coote 2011; Parks et al. 1981) to user innovation or consumer innovation (von Hippel 1986, 2005; von Hippel et al. 2011) and consumption as voting (e.g. Dickinson and Carsky 2005; Moraes et al. 2011; Shaw et al. 2006). Hence, it is appropriate to start focusing more on the consumers' role(s) in innovation processes.

In addition to this neglect in the innovation literature, (business) ethicists have not been passionate proponents of the demand side's role either. As Steve Tammelleo and Louis Lombardi recently observed:

"Unfortunately, discussions of ethics in economic activities have focused almost entirely on the responsibilities of businesses ... Those on the other side of the transaction are often viewed primarily as beings acted on" (Tammelleo and Lombardi 2014, p. 99).

However, various scholars have started to address this gap and developed the notion of consumer social responsibility (see e.g. Heidbrink and Schmidt 2011a, b, c; Schlaile et al. 2016; Schmidt 2016; Vitell 2003, 2015) in addition to the already well-established corresponding notion of corporate social responsibility (for a history see e.g. Carroll 2008; or Chap. 4 in Paine 2003). While this latter concept of corporate social responsibility (CSR) has also received much attention from the responsible innovation community (see Koops 2015, on a related note), the former concept of consumer social responsibility (ConSR) has thus far been neglected in the responsible innovation literature. 


\section{Individual, Collective, or Shared Responsibility?}

Although responsibility has advanced to an important notion in a business context (see also Heidbrink and Hirsch 2008), it is still an open issue which concept of responsibility is suitable for such complex, interdependent processes as (responsible) innovation in an increasingly globalized market economy. Consequences of actions may, for example, arise with geographical distance and time lags, and it is often also a mixture of (unforeseeable and unintended) consequences of individual and collective actions affecting others (see also Schlaile et al. 2016, on a related note). Hence, neither the notion of individual responsibility nor collective responsibility (see also French 1991, 1998, on related discussions) will be entirely fit for the purpose of responsible innovation. In order to adequately consider 'responsibilities' of all relevant actors in innovation networks, including actors from the public sector, corporations and consumers, we therefore propose to follow Iris Marion Young (2006, 2007, 2011), who developed a so-called social connection model of (shared) responsibility, which implies that "our responsibility derives from belonging together with others in a system of interdependent processes of cooperation and competition" (Young 2011, p. 105). Young also explains with reference to May's (1992) concept of shared responsibility:

"Shared responsibility ... is a personal responsibility for outcomes or the risks of harmful outcomes, produced by a group of persons. Each is personally responsible for the outcome in a partial way, since he or she alone does not produce the outcome; the specific part that each plays in producing the outcome cannot be isolated and identified, however, and thus the responsibility is essentially shared" (Young 2011, p. 110).

As also Imke Schmidt (2016) stresses, it is important to note, however, that Young's (2006, 2011) social connection approach to shared responsibility does not look for some kind of liability or blame as, for example, Kutz (2000) or May (1992). Instead, Young (2006, 2011) is solely interested in a prospective, forward-looking concept of responsibility that focuses on the agents" participation in (or contribution to) "blameable" social structures:

"Responsibility in relation to structural injustice derives ... from being positioned in the structures in relation to others and acting within these positions. The responsibility is general and shared rather than particular and individualized, as in the liability model. Responsibility from social connection says that those who act within unjust structures have a responsibility to try to make them more just" (Young 2011, p. 180).

With an eye to the aforementioned unsuitability of individual and collective responsibility concepts, Barnett et al. (2011) suggest that, in contrast to a blame-focused understanding of responsibility, this Youngian notion may provide a 'solution' as it "can negotiate between an undifferentiated claim of individual responsibility and an undiscriminating claim about collective responsibility" (Barnett et al. 2011, p. 8). More specifically, it seems applicable to innovation networks, as in the social connection approach "responsibility is distributed across complex networks of causality and agency" (ibid., emphasis added). On top of that, Stilgoe et al. (2013, p. 1569) also mention that an "important aspect of a forward-looking view of responsibility in science and innovation is that it is shared."

Despite its potential suitability for the context of responsible innovation, however, Young's (2006, 2011) approach is not without complications. As Christoph Henning (2015) elucidates, a potential problem with Young's model is that although individuals are responsible in these (unjust) social structures they are not responsible for them. Hence, according to Henning 
(2015), in practice, individuals may evade their duties as they could argue that they chose neither the structures nor their harmful effects (i.e. no intentionality is involved). However, Henning (2015) also proposes a solution to this issue based on Thomas Nagel's (2005) article on the problem of global justice. The argument may roughly be summarised as follows:

"Because economic structures have something compulsory about them but at the same time they occur in our name ..., we are obliged not only to perceive but also to recognise and, in practice, to accept this responsibility" (Henning 2015, p. 84, own translation, emphasis added). ${ }^{20}$

\section{Who's Got the Power?}

Several authors in the field of responsible innovation explicitly draw upon - or at least refer to - the works of Hans Jonas (1984) (see, for instance, Grinbaum and Groves 2013; Owen et al. 2012, 2013; Pavie and Egal 2014; Pavie et al. 2014). However, none of these contributions seem to consider the implications of Jonas' important statement that "responsibility is a correlate of power, so that the scope and kind of power determine the scope and kind of responsibility" (Jonas 1984, p. 128, emphasis added). This assertion clearly raises the question of what kind or concept of power would actually be suitable in the context of innovation. However, this topic seems to have been avoided by many responsible innovation scholars as well. $^{21}$

With recourse to our previous section, it is important to note that power is also central in Young's $(2006,2011)$ social connection approach to responsibility:

“An agent's position in structural processes usually carries with it a specific degree or potential or actual power or influence over processes that produce the outcomes" (Young 2011, p. 144, emphasis added).

In this regard, Barnett et al. (2011) add

"that responsibility does not, in theory or practice, arise simply from being connected to events, people, places and processes. It is differentiated according to capacities that actors can bring to bear to change things. For example, the question of power is one crucial dimension of this sense of shared responsibility - it is important to be able to discern the degree and type of influence that different actors have to change a situation" (Barnett et al. 2011, p. 8, italics in original).

Without delving too much into discussions that have been and should be carried out elsewhere, we follow Schlaile et al. (2016), who argue that the concept of power proposed by Carsten Herrmann-Pillath (2013) may be suitable in the context of networks and the social connection approach to responsibility. Note that although Schlaile et al. (2016) propose this

\footnotetext{
${ }^{20}$ The relevant passage in Nagel (2005) reads as follows: "Without being given a choice, we are assigned a role in the collective life of a particular society. The society makes us responsible for its acts, which are taken in our name and on which, in a democracy, we may even have some influence ..." (Nagel 2005, p. 129).

${ }^{21}$ Although they do not focus on the development of a suitable concept of power, Blok et al. (2015) at least mention explicitly that power imbalances can be a reason for conflicts among the actors and stakeholders involved in responsible innovation processes. "Some actors are even unwilling to interact when they have the feeling that they have less or no power compared with other actors involved" (Blok et al. 2015, p. 152).
} 
argument in the context of ConSR, the reference to shared responsibility as well as networks is identical and can thus be applied to a 'social connection approach' to responsible innovation and innovation networks. With prior reference to Sen's (1999) capability approach, Herrmann-Pillath writes:

\begin{abstract}
"The theoretical concept of 'power' relates to patterns of causation in network evolution and is a property of network configurations of actors that is only assigned to (but not ontologically manifest in) actors because it is reflected in successful interactions of actors. ... [P]ower relates with capabilities of actors that are emergent in network configurations. For example, an actor might control essential gateways in information flows, and possesses the capacity and knowledge to exploit this configuration" (Herrmann-Pillath 2013, p. 326).
\end{abstract}

We suggest that it may be suitable and useful to adopt this notion especially in discussions of responsibility in the context of innovation networks. ${ }^{22}$

\title{
Synthesis: An Agent-based Simulation Model of Heterogeneous Consumers and Their Impact on Responsible Innovations
}

In this section, we present an agent-based simulation model that is designed to analyse and illustrate potential effects of consumers' heterogeneity. In more detail, we aim to show the consequences of consumers' heterogeneity (particularly regarding their preferences) and their bounded rationality (and, in a certain sense, bounded morality) ${ }^{23}$ within an evolutionary economic framework on the creation and diffusion of innovations, including 'responsible' ones. As noted above, moral interests and preferences differ between consumers (as do preferences in general), which means that traditional approaches using representative agents cannot be applied. Instead, we are dealing with dynamic processes within a complex system characterized by (interdependent) heterogeneous agents, or diversity of agents (in terms of attributes, types, or configurations; see Page 2011). Consequently, including heterogeneous and boundedly rational consumers into the analysis of innovation processes calls for new modelling approaches suited to analyse these complex phenomena (Farmer and Foley 2009; Gilbert 2008; Pyka and Fagiolo 2007; Pyka and Grebel 2006; Tubaro 2011).

Since the 1980s, continuous improvements in computer technologies have remarkably changed scientists' possibilities to develop and apply computer simulations. Simulations as a scientific tool offer new ways to explore the dynamics of complex models in various disciplines. They enable us to process scientists' thought models into artificial test laboratories where we can systematically analyse the models' outcomes. This is especially useful for

\footnotetext{
${ }^{22}$ Note that this relational concept of power is also in line with Michel Foucault's understanding of power as a "productive network which runs through the whole social body" (Foucault 1980, p. 119), emerging "from socially and historically situated interactions" (Moraes et al. 2011, p. 1060).

${ }^{23}$ The notion of bounded morality has been proposed by Schlaile et al. (2016, no pagination, yet) and can be understood "as the boundary or limiting condition that an agent's (here: a consumer's) morality and in-group may be limited due to internal (e.g., neocortical volume and information-processing capacity) and external (e.g., pluralistic world views and moral codes due to social learning and integration into a complex networked society) factors that can be regarded as the results of biological and cultural evolutionary processes." In short, consumers are neither perfectly rational nor perfectly moral individuals.
} 
tackling wicked problems such as responsible innovation because simulation results may reveal scenarios where the outcomes or 'solutions' are better or worse than in others.

Within the broad field of simulation techniques, the so-called agent-based modelling (henceforth $\mathrm{ABM}$ ) approach has gained increasing momentum not only for economics but also in many other scientific disciplines (e.g. Boero et al. 2015; de Marchi and Page 2014; Hamill and Gilbert 2016; Kiesling et al. 2012; Mueller and Pyka 2017; Namatame and Chen 2016; Vermeulen and Pyka 2016; Wilensky and Rand 2015). The ABM approach focuses on the rules and elements constituting a system as well as the actions and interactions of these entities as the relevant actors within that system. ${ }^{24}$ It is, therefore, particularly in line with the processual and evolutionary 'philosophy of organism' sketched above. This perspective of $\mathrm{ABM}$ is accompanied by the attempt to represent actors of economic systems in a more realistic fashion, thereby overcoming the shortcomings of approaches limited to representative agents which, by definition, ignore diversity and the related implications of interacting heterogeneous agents (see e.g. Bonabeau 2002; Macal and North 2005, 2006, 2010, 2014; Page 2011). Quite recently, ABM has also been proposed as a valid method for studying various scenarios in the context of responsible innovation (e.g. Flipse et al. 2015; Schilperoord et al. 2015).

The agent-based simulation model described in this paper is based on the work by Mueller et al. (2015) and represents a first attempt to particularly address the above issue of neglected consumers in (responsible) innovation research. Consequently, the model does not yet incorporate all of the aspects discussed above. Instead, we will focus on the effects of heterogeneous and boundedly rational consumers on innovation processes. In a second step, we apply this model to an analysis of the creation and diffusion of responsible innovations. In this regard, it is important to note that the current model captures only parts of the consumers' demand-side responsibility, namely consumption as voting (Dickinson and Carsky 2005; Moraes et al. 2011; Shaw et al. 2006), ${ }^{25}$ whereby consumers ultimately (collectively) select which innovations (e.g. new products or services) and firms (suppliers) remain in the market. As Roger Dickinson and Mary Carsky put it:

"Consumers participate in creating the societies of which they are a part by their purchases, just as they may influence their environments by their votes in political elections" (Dickinson and Carsky 2005, p. 25).

Our simulation model is inspired by Kelvin Lancaster $(1966,1975,1979)$ and allows for heterogeneity of demand based on heterogeneous consumers equipped with individual preferences for the particularities of an innovation's characteristics (e.g. the particular colour or size, the functionality, included services, etc.). This individual concept includes a full image of a preferable innovation within a multidimensional characteristic space. With this we aim to introduce a general framework model of interaction between heterogeneous producers and heterogeneous consumers in an environment where firms are forced by the innovative activities of competitors to continuously adapt to market conditions. The brief introduction of the model should illustrate the possibilities of the ABM approach to include responsibility issues into the analysis of dynamic innovation processes with heterogeneous actors on the supply as well as the demand side.

\footnotetext{
${ }^{24}$ It is particularly the interactions that also give rise to emergent phenomena (Wilensky and Rand 2015).

${ }^{25}$ See also Fig. 1 in Schlaile et al. (2016) for a possible categorisation of spheres and domains where consumers can make responsible decisions (i.e. the so-called consumer responsibility territory).
} 
Our starting point for the analysis is a standard scenario introduced by Mueller et al. (2015) which aims to show the fundamental impacts of consumer heterogeneity on the innovative behaviour of firms. In this article, we use an extended version for investigating the effect of different levels of consumers' bounded rationality on the creation and diffusion of (responsible) innovations. The special feature of our simulation model is that innovations also feature negative, i.e., 'harmful' characteristics, including energy consumption, environmental issues and other characteristics related to Blok and Lemmens' "Faustian" aspect of innovation mentioned above. Additionally, inspired by the distinction proposed by Harsanyi (see previous section), consumers can be characterised individually by personal and moral preferences. However, not all consumers have the same (strength of) moral interests or preferences. Hence, in our model consumers are also heterogeneous in the way they recognise and evaluate negative characteristics. While some consumers explicitly consider negative characteristics others neglect them and focus on their personal preference for the main characteristics as in the previous models. In this way, we analyse the effect of more responsible or morally interested consumers (i.e. consumers who consider also "Faustian aspects") on the innovation process and, hence, the implications for a shift towards more responsible innovation in a market.

\section{Model Description}

Following the ideas of Lancaster (1966, 1975, 1979), innovations in the simulation exhibit a large set of characteristics forming a multidimensional characteristics space. Other models using this idea are, for example, Saviotti and Metcalfe (1984), Saviotti (1996), Gallouj and Weinstein (1997) and Valente (2012). This set of characteristics $A_{j, i}$ is represented by a bit string of finite length, defining all possible combinations of characteristics for a specific innovation $j$ of a firm $i$. For example, we depict a possible innovation and its set of characteristics as represented in (1), which yields a total of $2^{20}=1,048,576$ possible states:

$$
A_{j, i}=1,0,0,0,1,1,0,1,0,1,0,0,1,1,0,1,0,0,1,0
$$

Many innovation models have characterised innovations only by price and quality. In our model, incorporating a large set of different characteristics enables us to get closer to the complexity and uncertainty of firms' innovation processes as well as conflicting relations of single characteristics concerning their impact on responsibility. Although price and quality represent two crucial characteristics of products and services, we have to acknowledge that consumers evaluate innovations based on a much larger set of characteristics, including branding, colour, size, shape, etc. Only through this broad conception, demand may become diverse and heterogeneous.

The procedures of the simulation are implemented as follows (for details see Mueller et al. 2015):

- Each firm produces an innovation (e.g. new product or service) based on its individual knowledge stock.

- Consumers analyse all products available, purchasing the innovation best matching the consumers' preferences.

- Firms engage in research and development (R\&D) in accordance with their innovation strategy.

- Firms without sales for more than five periods exit the market and a constant number of new, randomly generated firms enter the market. 
After the development of innovations, consumers choose and buy - according to their perspective - the best fitting one. Obviously, a full fit between an innovation offered by a firm and the one desired by a consumer can only rarely be observed. In order to determine the match between those characteristics demanded by consumers and those offered by firms (i.e. consumer preference match, henceforth CPM), the Hamming distance (Hamming 1950) is applied; i.e. first it is determined on how many positions over all characteristics the innovation offered differs from the desired one. This number is then divided by the maximum number of digits. In a next step, firms decide on their R\&D strategy. Innovation in our simulation is a highly uncertain process which involves the (re-)combination of knowledge (Dosi 1988). A firm's engagement in R\&D is based on two criteria, both of which are conceptualised as thresholds within the firms' decision routines (see e.g. Nelson and Winter 1982). First, we define a firm's market share $S_{i}$ as firm $i$ 's share of consumers having demand for innovations of firm $i$. If the market share is low (below the threshold for radical research $h^{r}$ ) the firm will engage in radical R\&D. This means that a firm is deleting one of its knowledge units entirely and replacing it with another knowledge unit randomly chosen. Radical R\&D can therefore be interpreted as the attempt of a firm to search for new market niches since the potentially new characteristics will be perceived very differently by the consumer side. Furthermore, for cases in which the firm's market share is above the radical threshold but still below the threshold for incremental research $h^{i}$ the firm will engage in incremental R\&D. The respective firm only changes one bit of one of its randomly chosen knowledge units, thereby trying to more successfully adapt to the needs of consumers in an existing market niche. With a firm's market share being high enough (i.e. above the incremental threshold) the firm no longer engages in R\&D. This means that the respective firm is satisfied with its market position and avoids the risk of possible negative consequences concerning the probability that innovations are not acknowledged by many consumers. Finally, we assume that each time step a constant number of new firms enter the market in an entrepreneurial fashion.

The major result of the standard model is that allowing for heterogeneous demand creates highly unstable dynamics with varying but endogenous incentives to innovate. Instead of creating a situation in which technological leaders become established, we find a persisting dynamic situation in which firms are unable to occupy stable market shares. Since even for a small niche a full match between innovations supplied and demanded is highly unlikely there is always the chance for competitors to entice customers. This in turn is a constant challenge for the firms involved in that niche: firms are forced to engage in $R \& D$ activities to regain market share.

In the following paragraphs we now explicitly consider 'responsible' or 'morally interested' consumers by additionally considering negative or harmful characteristics of innovations.

\section{Responsible Innovation - Baseline Scenario}

To implement negative characteristics, we introduce a second set of characteristics represented again by a bit string of $2^{20}$ possible states for each innovation. While for the first set of characteristics we continue to assume heterogeneous demand, the potential demand for the second characteristics, which represent potentially harmful impacts of the product or service, is fixed for all consumers (indicated by an identical bit string). As this second set of characteristics represents only an abstract and simplified representation of all harmful characteristics of an innovation, we cannot measure the negative effects of an innovation directly. Instead, we 
capture the 'responsibility' of an innovation based on the (inverted) Hamming distance between the socially optimal characteristics (SOC), which is randomly predefined for each innovation during the initialisation of the simulation, and the second characteristics of a firm's product or service. This abstract and hypothetical SOC could be interpreted in terms of the results of a social discourse that will be striven for by 'responsible consumers' by comparing the innovation's characteristics with the SOC. ${ }^{26}$

To mirror the individual acknowledgement of the negative characteristics some consumers are assumed to evaluate innovations based on both characteristics (responsible or "morally interested' consumers) while others simply do not care about harmful effects or "Faustian aspects". Responsible consumers, however, weight the individual importance of characteristics based on the 'bounded morality' parameter $\gamma$, so e.g. if $\gamma=0$ they also neglect negative characteristics and for $\gamma=1$ they fully focus on the negative characteristics and do not consider any other (in other words, $\gamma$ represents the strength of a consumer's moral interests in a very simple fashion). The ratio between consumers not considering negative characteristics and responsible consumers is given by $\delta$, indicating that for $\delta=1$ all consumers are responsible consumers and for $\delta=0$ no responsible consumers exist. ${ }^{27}$

Figure 1 shows the resulting CPM levels (left hand side) and match with the SOC (right hand side) for a situation of homogeneous and heterogeneous consumer demand over time for $\gamma=0.5$ and $\delta=0.5$, meaning that half of the consumers consider the negative characteristics and evaluate them equally with other personal preferences for the characteristics of an innovation. Note that the 'match with SOC' represents how closely the offered innovations match the SOC (in terms of the inverted Hamming distance between SOC and the characteristics of the innovations that are offered by the firms). Interestingly, we see that heterogeneity of demand has a positive effect (after about 50 periods) for the resulting 'match with SOC', while at the same time impairing the average CPM level.

The explanation for this is that in markets with homogeneous demand there is considerably less innovation than in markets with heterogeneous demand. In this scenario the market can be divided into consumers simply neglecting negative characteristics and consumers equally considering both sets of characteristics. Measuring the average match of all innovations with the theoretical criteria of SOC, we see that markets fail to produce these innovations in case the normal consumer demand is homogeneous. Homogeneous consumer demand, however, does not provide space for segmentation. Instead, we see the emergence of only two separated niches, i.e. separated submarkets, one for responsible consumers and one for regular consumers. This in turn leads to markets with only few innovations with the consequence that the average match of innovations with the SOC is lower than in the case of heterogeneous demand.

If we increase the level of heterogeneity of consumer demand, the clear boundaries between the two niches are watered down and firms produce a large variety of innovations. With this they also produce "better", i.e. more responsible innovations despite the fact that the number of consumers considering negative characteristics remains constant. However, looking at the average CPM levels of consumers, i.e. the match between the characteristics demanded by all

\footnotetext{
${ }^{26}$ In reality, of course, any SOC will be hard or even impossible to find, due to the wicked problem characteristics mentioned in the introduction. This means that the SOC remains rather hypothetical in a similar sense as a Rawlsian veil of ignorance (Rawls 1999).

${ }^{27}$ Note that our model does not distinguish motivations for considering negative characteristics. In other words, and with an eye to our above section on moral interests, at this point we do not make any assumptions about whether consumers consider negative characteristics out of 'sympathy' towards those affected by the innovation's harmful consequences or out of 'commitment'.
} 

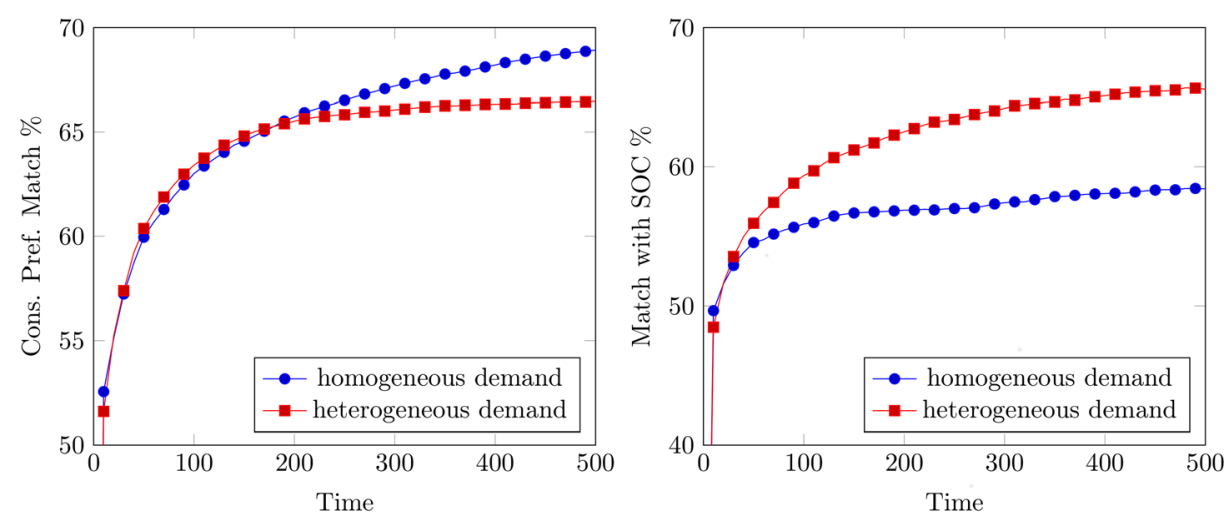

Fig. 1 CPM Levels and Match with SOC for Homogeneous vs. Heterogeneous Demand

consumers (considering negative characteristics or not) and the characteristics of innovations they purchase, we see that heterogeneous markets may also have adverse effects which can be explained by the great variety of innovations demanded. In case of homogeneous consumer demand, innovation efforts of firms are focused. In contrast, heterogeneous consumer demand creates a situation where firms have to focus on small niches and, hence, can only provide compromise solutions and thus fail to match consumer demand.

To analyse the effects of different degrees of $\gamma$ and $\delta$ in more detail, we show in Fig. 2 the average match of innovations with the SOC achieved in a market of heterogeneous but fully informed consumers after 500 simulation steps.

In a market with full consumer information both factors $\gamma$ and $\delta$ are of decisive importance and the highest consideration of negative characteristics is achieved if all consumers evaluate innovations based on negative characteristics only. While this result can be considered as straightforward, we also see that in situations with only a few 'responsible consumers' $(\delta<0.4)$ the markets fail to produce innovations matching the SOC even if these consumers base their decision solely on negative characteristics $(\gamma>0.8)$. In other words, for 'responsible' innovations to occur, markets need at least a partially balanced composition of both factors $\gamma$ and $\delta$.

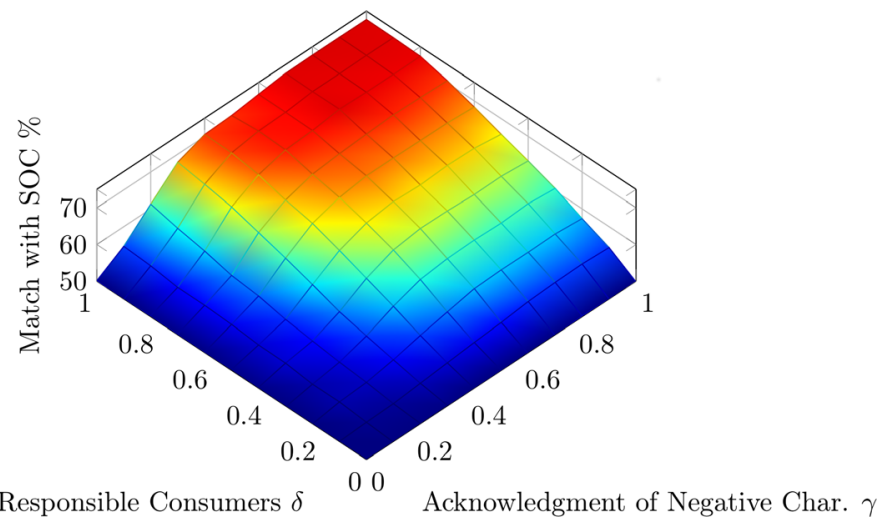

Fig. 2 Match with SOC in a Fully Informed Market 


\section{Responsible Innovation - Limited Information}

One of the central simplifications in the previous scenario is the assumption of perfectly informed consumers, meaning that all consumers always have full information about all firms, their innovations and the particular characteristics as well as their own personal preferences. We extend the existing baseline scenario and analyse the changes in the behaviour of the simulation model if we introduce limited information. Consumers in this scenario are not automatically informed about innovations and their characteristics. While the assumption of full information in our previous scenario may be to some extent justifiable in small markets with a manageable number of firms and innovations and well-informed consumers actively seeking for new information, consumer capabilities in large markets are clearly limited. This has strong effects on the innovation process of firms (Valente 2009, 2012). Therefore, instead of assuming perfectly informed consumers, we follow Herbert Simon's idea of bounded rationality of economic actors (Simon 1955, 1959, 1972, 1997) also for consumers and assume only limited availability and processing capability of information about firms and the products and services they offer (see also Schlaile et al. 2016, on the related problem of informational complexity). In this scenario firms actively send information to a small number of randomly chosen consumers every time step. This way we create a constant information scarcity on the consumer side and, hence, introduce an additional factor of diversity or heterogeneity among consumers.

As Fig. 3 shows, the average match of innovations with the SOC clearly has its maximum if half of the consumers are responsible $(\delta=0.5)$ and evaluate both regular and negative characteristics equally $(\gamma=0.5)$ which stands in clear contrast to the results gained in the previous subsection. For higher values of $\gamma$ or $\delta$, the market approaches a situation where all consumers show the same demand (considering only the negative characteristics of an innovation) and, hence, approach a situation of homogeneous consumer demand. This, however, leads to less firms and, thus, less innovation in the market (see Fig. 4). As a result, we see a responsibility gap, which appears if the market consists only of consumers focusing solely on negative characteristics. In other words, our results indicate an unexpected optimal composition of markets. Clearly, if nobody wants responsible innovations, firms will not produce them. At the same time, however, if everybody considers only the harmful effects or negative characteristics (i.e. consumers only follow their 'moral interests') and neglects

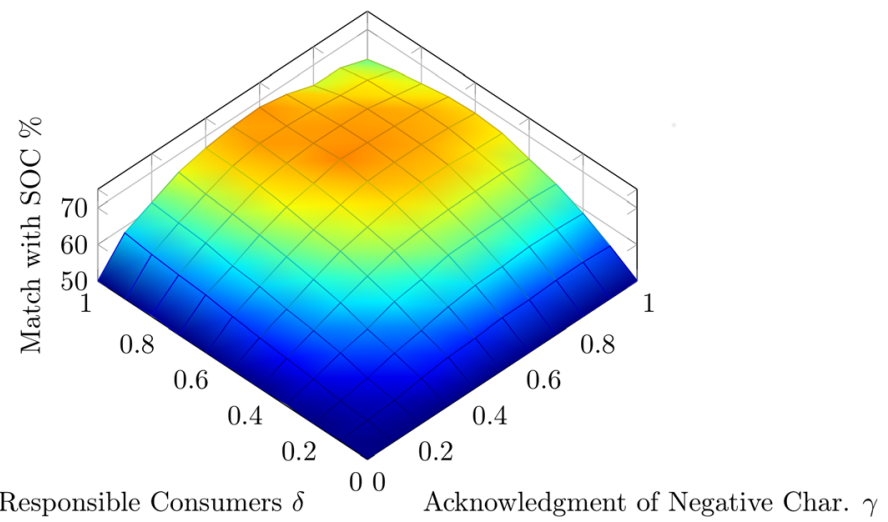

Fig. 3 Match with SOC with Limited Information 


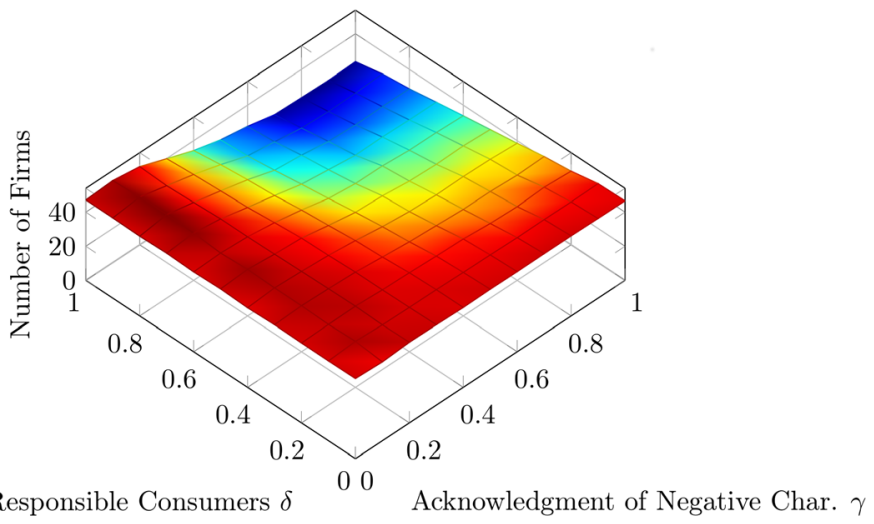

Fig. 4 Number of Firms for Different $\gamma$ and $\delta$

personal preferences, we may observe a homogeneous market where temporary monopolies hinder innovation and, consequently, limit the potential for major improvements.

To summarise, this scenario clearly illustrates how the dynamics in the markets change if we abandon the straightforward and limiting assumption of perfectly rational and informed consumers. Although one might expect that the best innovations are produced if all consumers only consider the negative characteristics, the market dynamics underlying the creation and production of new innovations interestingly create a situation where less 'responsible' innovations are produced than in a situation where some consumers consider negative characteristics and some do not. In other words, to implement responsibility considerations in innovation processes, already a smaller number of consumers might be sufficient for a shift towards responsible innovation.

\section{Conclusion}

Undoubtedly, problems such as responsible innovation cannot be appropriately tackled by means of approaches that oversimplify the inherent nature of the phenomenon at hand. Instead, we have to look for alternatives offering a more suitable framework for studying the collective and complex dynamics involved. In this paper, we have contributed to the discussion of responsible innovation in (at least) two ways. First, we have presented some arguments for an evolutionary perspective for the analysis of innovation in general and responsible innovation in particular. One of the central advantages of the evolutionary (economic) perspective is that it is better able to address the complex, interdependent and dynamic nature of (responsible) innovation processes - including wicked problem characteristics - than traditional approaches of (mainstream) economics. Moreover, the approach proposed in this paper can incorporate diversity or heterogeneity of economic actors, including heterogeneous preferences, which also involve moral interests.

Second, we have discussed some neglected ethical issues and implications, particularly moral interests, the neglected consumers in (responsible) innovation and business ethics research, shared responsibility and the concept of power in this context. 
With regard to innovation networks, the link between the social connection approach to shared responsibility and the notion of power proposed above paves the way for future research rooted in network science (e.g. Barabási 2016; Newman 2010) or social network analysis (e.g. Wasserman and Faust 1994) in order to identify central actors that actually have the power or influence to act responsibly. Such a network approach may also help to address an issue identified by Blok et al. (2015, p. 156), namely that in practice it seems that "in industrial or private sector innovation processes, companies do not share responsibility for innovations with stakeholders."

As an additional pillar, we have presented the results of an agent-based simulation model as a first attempt to demonstrate and display the possibilities of using a framework as discussed above to design a numeric model suited for the analysis of responsible innovation. Our analysis illustrates that consumers play an important role in the creation and diffusion of responsible innovations. Possibly the most striking result of the model is that when we allow for heterogeneity, dynamics and bounded rationality of agents, any 'simple solutions' disappear. Our results suggest that a "responsibility gap" might emerge: when all consumers focus solely on negative characteristics and demand only "responsible" products and services, it may be the case that a situation is created that is inferior compared to scenarios where some consumers neglect negative impacts of innovations. In this scenario markets tend to establish monopoly structures, which in turn are less efficient in terms of innovation. With an eye to the wicked problem characteristics of responsible innovation, in the monopoly situation, firms may neglect investments in innovations and technologies that could contribute to the solution of societal problems in a better way. Undoubtedly, our model still has limitations and is only a first attempt to move in the direction of analysing questions related to responsible innovation with this method. For example, at this stage, the model only captures a small part of the many potential roles of consumers in responsible innovation, particularly that of consumers as voters, which is just one of the consumers' demand-side responsibilities (see also Schlaile et al. 2016). Evidently, the role of consumers goes beyond being the selecting entity for responsible products or services. Consumers can, for example, also make responsible decisions with regard to information procurement (and dissemination), in terms of consumer activism and citizenship, co-production and co-creation of value, responsible usage and disposal, etc. (Schlaile et al. 2016). However, focusing on this particular role of consumers as selectors of responsible innovations (and thus also in a sense promoting corporate responsibility) can be deemed necessary, as it can generate insights that would otherwise be overlooked. In the words of Devinney et al. (2010), one could even expand the idea of consumer responsibility

"to discuss the social responsibility of the citizen ... Social consumption then becomes part of the role of the individual in a monitory form of democracy ... We can therefore speak about the individual as having a variety of social responsibilities - as consumer, citizen, worker, investor, and so on - each of which gives us a different angle on the complex embodiment of the individual in the different roles and contexts ... [L]ooking at consumption is only one window on the individual. But it is a window worth looking through" (Devinney et al. 2010, p. 187).

In other words, the real world is far more complex than our present model (or any economic model, for that matter) and there are various other aspects and factors that influence 
(responsible) innovation processes, which can, in principle, be included in an agent-based model, though. ${ }^{28}$ As George Box put it in a different but related context:

“All models are wrong but some are useful ... [C] ]unningly chosen parsimonious models often do provide remarkably useful approximations. ... For such a model there is no need to ask the question 'Is the model true?'. If 'truth' is to be the 'whole truth' the answer must be 'No'. The only question of interest is 'Is the model illuminating and useful?'” (Box 1979, pp. 202-203, emphasis removed).

Consequently, the perspective proposed in this paper should be seen as a starting point for further work and as a much needed attempt to raise awareness for the important role of consumers. After all, the results presented above already yield important implications for researchers, firms and also policy makers, including that a focus on corporate social responsibility may be insufficient and that consumer social responsibility should be addressed as well. Hence, the model deliberately focuses only on some - in our opinion crucial and yet insufficiently studied - aspects of the complex system of responsible innovation, namely the consumer side. Since we are dealing with complex issues and wicked problems, there are neither simple nor generalizable policy implications, though. With an eye to our evolutionary perspective on responsible innovation, we do, however, agree with Mariana Mazzucato (2016, p. 271), who writes: "Innovation policy must focus on building more 'symbiotic' (less parasitic) innovation 'ecosystems"'. Policies aimed at promoting responsible innovation should therefore address all actors within innovation networks with sufficient capabilities and influence to contribute towards making this complex system more 'responsible'. For consumers, this means accepting their share of responsibility, whereas institutional support (e.g. by the state) - including consumer education - may also prove necessary for consumer empowerment. This, in turn, requires further work on the discussion whether and under which circumstances paternalism is justified (see also Binder 2014, on a related note).

Building on these insights, one can stepwise increase the complexity of the model in future research by introducing further aspects, agents and/or other elements. More specifically, future research can extend the current work in at least two ways. First, we need detailed empirical studies - including case studies (see also Newholm 2005) - that focus on consumers and their particular roles and capabilities in responsible innovation processes. These studies can be used as a complement to models as well as to test and improve them in terms of calibration and validation. Second, one should extend the scope of the model presented above and, for example, include further economic actors in the innovation network (e.g. research institutes, non-governmental organisations, public or governmental actors, etc.) and analyse their particular impact and influence as well as their 'share' in responsibility (in terms of the power concept proposed above) within the innovation process.

Acknowledgements We would like to thank the participants of our session at the Philosophy of Management Conference, 14-17 July 2016 at St Anne's College in Oxford, for helpful comments, questions and criticism. Special thanks are due to Vincent Blok not only for chairing and organising the special track on 'philosophy of innovation, responsible innovation, and innovation ethics' but also for his invaluable advice and suggestions. We are also indebted to the three anonymous reviewers who helped improve the quality of this paper and to Johannes Zeman for helpful remarks. Any remaining errors or omissions remain the authors' responsibility. Matthias Mueller acknowledges financial support from the Dieter Schwarz Stiftung.

\footnotetext{
${ }^{28}$ As Scott de Marchi and Scott E. Page (2014, p. 11) put it, "almost anything can be implemented with good computer science skills." We can also follow Axtell and Epstein (1994) as well as Gilbert and Terna (2000) by saying that we cannot understand artificial systems any better than we understand the real ones if they are too complex.
} 


\section{Compliance with Ethical Standards}

Conflict of Interest The authors declare that they have no conflict of interest.

Open Access This article is distributed under the terms of the Creative Commons Attribution 4.0 International License (http://creativecommons.org/licenses/by/4.0/), which permits unrestricted use, distribution, and reproduction in any medium, provided you give appropriate credit to the original author(s) and the source, provide a link to the Creative Commons license, and indicate if changes were made.

\section{References}

Allen, P.M. 1988. Evolution, innovation and economics. In Technical change and economic theory, ed. G. Dosi, C. Freeman, R. Nelson, G. Silverberg, and L. Soete, 95-119. London: Pinter.

Allen, P.M. 2015. Evolution: Complexity, uncertainty and innovation. In The evolution of economic and innovation systems, ed. A. Pyka and J. Foster, 145-170. Cham: Springer.

Andersen, E.S. 2007. Innovation and demand. In Elgar companion to neo-Schumpeterian economics, ed. H. Hanusch and A. Pyka, 754-765. Cheltenham: Edward Elgar.

Andersen, S., S. Ertaç, U. Gneezy, M. Hoffman, and J.A. List. 2011. Stakes matter in ultimatum games. The American Economic Review 101(7): 3427-3439.

Antonelli, C. and G. Ferraris. 2011. Innovation as an emerging system property: An agent based simulation model. Journal of Artificial Societies and Social Simulation 14(2): 1. doi:10.18564 /jasss.1741.

Antonelli, C., and G. Scellato. 2008. Out of equilibrium profit and innovation. U. of Torino Department of Economics Research Paper, 4.

Arthur, W.B. 2015. Complexity and the economy. Oxford: Oxford University Press.

Axelrod, R. 1997. Advancing the art of simulation in the social sciences: Obtainig, analyzing, and sharing results of computer models. Complexity 3(2): 16-22.

Axtell, R.L., and J.M. Epstein. 1994. Agent-based modeling: Understanding our creations. The Bulletin of the Santa Fe Institute 9(2): 28-32.

Barabási, A.-L. 2016. Network science. Cambridge: Cambridge University Press.

Barnett, C., P. Cloke, N. Clarke, and A. Malpass. 2011. Globalizing responsibility: The political rationalities of ethical consumption. Chichester: Wiley.

Beckenbach, F., and J. Nill. 2005. Ökologische Innovationen aus Sicht der evolutorischen Ökonomik. In Jahrbuch Ökologische Ökonomik 4: Innovationen und Nachhaltigkeit, ed. F. Beckenbach, U. Hampicke, C. Leipert, G. Meran, J. Minsch, et al., 63-85. Marburg: Metropolis.

Beinhocker, E.D. 2006. The origin of wealth: Evolution, complexity, and the radical remaking of economics. Boston: Harvard Business School Press.

Beisbart, C. 2012. How can computer simulations produce new knowledge? European Journal for Philosophy of Science 2(3): 395-434.

Bessant, J. 2013. Innovation in the twenty-first century. In Responsible innovation: Managing the responsible emergence of science and innovation in society, ed. R. Owen, J. Bessant, and M. Heintz, 1-25. Chichester: Wiley.

Binder, M. 2014. Should evolutionary economists embrace libertarian paternalism? Journal of Evolutionary Economics 24(3): 515-539.

Blok, V., and P. Lemmens. 2015. The emerging concept of responsible innovation. Three reasons why it is questionable and calls for a radical transformation of the concept of innovation. In Responsible innovation 2: Concepts, approaches, and applications, ed. B.-J. Koops, I. Oosterlaken, H. Romijn, T. Swierstra, and J. van den Hoven, 19-35. Cham: Springer.

Blok, V., L. Hoffmans, and E.F.M. Wubben. 2015. Stakeholder engagement for responsible innovation in the private sector: Critical issues and management practices. Journal on Chain and Network Science 15(2): 147164.

Boero, R., M. Morini, M. Sonnessa, and P. Terna. 2015. Agent-based models of the economy: From theories to applications. Basingstoke: Palgrave Macmillan.

Bohm, D. 1969. Some remarks on the notion of order. In Sketching theoretical biology. Toward a theoretical biology, Vol. 2 (2010 paperback ed., pp. 18-60), ed. C. H. Waddington. New Brunswick, NJ: Transaction Publishers. 
Bolton, G.E. 1991. A comparative model of bargaining: Theory and evidence. The American Economic Review 81(5): 1096-1136.

Bonabeau, E. 2002. Agent-based modeling: Methods and techniques for simulating human systems. PNAS 99(suppl. 3): 7280-7287. doi:10.1073/pnas.082080899.

Boulding, K.E. 1969. Economics as a moral science. The American Economic Review 59(1): 1-12.

Box, G.E.P. 1979. Robustness in the strategy of scientific model building. In Robustness in statistics, ed. R.L. Launer and G.N. Wilkinson, 201-236. New York: Academic.

Buchmann, T., and A. Pyka. 2012. Innovation networks. In Handbook on the economics and theory of the firm, ed. M. Dietrich and J. Krafft, 466-482. Cheltenham: Edward Elgar.

Buenstorf, G., U. Cantner, H. Hanusch, M. Hutter, H.-W. Lorenz, and F. Rahmeyer. 2013. Editorial: The two sides of innovation. In The two sides of innovation: Creation and destruction in the evolution of capitalist economies, ed. G. Buenstorf, U. Cantner, H. Hanusch, M. Hutter, H.-W. Lorenz, and F. Rahmeyer, 1-7. Cham: Springer.

Carroll, A.B. 2008. A history of corporate social responsibility: Concepts and practices. In The Oxford handbook of corporate social responsibility, ed. A. Crane, A. McWilliams, D. Matten, J. Moon, and D.S. Siegel, 1946. Oxford: Oxford University Press.

Cartwright, E. 2014. Behavioral economics, 2nd ed. London: Routledge.

Conklin, J. 2006. Dialogue mapping: Building shared understanding of wicked problems. Chichester: Wiley.

Coombs, R., K. Green, A. Richards, and V. Walsh. 2001. Introduction. In Technology and the market: Demand, users and innovation, ed. R. Coombs, K. Green, A. Richards, and V. Walsh, 1-11. Cheltenham: Edward Elgar.

Coote, A. 2011. Co-production as a vehicle for sharing social responsibilities. Trends in Social Cohesion 23: 291-309.

Courvisanos, J. 2007. The ontology of innovation: Human agency in the pursuit of novelty. History of Economics Review 45: 41-59.

Csikszentmihalyi, M. 2014. The systems model of creativity and its applications. In The Wiley handbook of genius, ed. D.K. Simonton, 533-545. Chichester: Wiley.

Davies, P., and J. Gribbin. 1992. The matter myth: Dramatic discoveries that challenge our understanding of physical reality (Reissue 2007 ed.). New York: Simon \& Schuster.

de Marchi, S., and S.E. Page. 2014. Agent-Based Models. Annual Review of Political Science 17(1): 1-20.

Devinney, T.M., P. Auger, and G.M. Eckhardt. 2010. The myth of the ethical consumer. Cambridge: Cambridge University Press.

Dibben, M.R. 2004. Exploring the processual nature of trust and cooperation in organisations: A Whiteheadian analysis. Philosophy of Management 4(1): 25-39.

Dibben, M.R. 2009. Organisations and organising: Understanding and applying Whitehead's processual account. Philosophy of Management 7(2): 13-24.

Dickinson, R.A., and M.L. Carsky. 2005. The consumer as economic voter. In The ethical consumer, ed. R. Harrison, T. Newholm, and D. Shaw, 25-36. London: Sage.

Dierksmeier, C. 2016. Reframing economic ethics: The philosophical foundations of humanistic management. Basingstoke / Berlin: Palgrave Macmillan / Springer Nature.

Dobusch, L., and J. Kapeller. 2009. "Why is economics not an evolutionary science?" New answers to Veblen's old question. Journal of Economic Issues 43(4): 867-898.

Dopfer, K. (ed.). 2001. Evolutionary economics: Program and scope. New York: Springer.

Dopfer, K. (ed.). 2005. The evolutionary foundations of economics. Cambridge: Cambridge University Press.

Dopfer, K. 2007. Grundzüge der Evolutionsökonomie - Analytik, Ontologie und theoretische Schlüsselkonzepte. Discussion Paper no. 2007-10. St. Gallen: University of St. Gallen.

Dopfer, K. 2016. Evolutionary economics. In Handbook on the history of economic analysis, ed. G. Faccarello and H.D. Kurz, 175-193. Cheltenham: Edward Elgar.

Dopfer, K., and J. Potts. 2008. The general theory of economic evolution. Abingdon: Routledge.

Dosi, G. 1988. Sources, procedures, and microeconomic effects of innovation. Journal of Economic Literature 26(3): 1120-1171.

Eason, R., R. Rosenberger, T. Kokalis, E. Selinger, and P. Grim. 2007. What kind of science is simulation? Journal of Experimental \& Theoretical Artificial Intelligence 19(1): 19-28.

Edler, J., and L. Georghiou. 2007. Public procurement and innovation - Resurrecting the demand side. Research Policy 36(7): 949-963.

Evensky, J. 2005. Adam Smith's moral philosophy: A historical and contemporary perspective on markets, law, ethics, and culture. Cambridge: Cambridge University Press.

Fagerberg, J., D.C. Mowery, and R.R. Nelson (eds.). 2005. The Oxford handbook of innovation. Oxford: Oxford University Press.

Fagerberg, J., B.R. Martin, and E.S. Andersen (eds.). 2013. Innovation studies: Evolution and future challenges. Oxford: Oxford University Press. 
Farmer, J.D., and D. Foley. 2009. The economy needs agent-based modelling. Nature 460(7256): 685-686.

Flipse, S. M., J.H. De Winde, P. Osseweijer, and M.C.A. van der Sanden. 2014. The wicked problem of socially responsible innovation. EMBO reports 15(5): 464.

Flipse, S.M., J.O. Vrielink, and M.C.A. van der Sanden. 2015. Building interactive communication tools to support interdisciplinary responsible innovation. Journal of Innovation Management 3(4): 119-133.

Fontana, R., and M. Guerzoni. 2008. Incentives and uncertainty: An empirical analysis of the impact of demand on innovation. Cambridge Journal of Economics 32(6): 927-946.

Foucault, M. 1980. Power/Knowledge: Selected interviews \& other writings 1972-1977. (ed. C. Gordon) New York: Pantheon.

Frantz, R., S.-H. Chen, K. Dopfer, F. Heukelom, and S. Mousavi (eds.). 2017. Routledge handbook of behavioral economics. Abingdon: Routledge.

French, P.A. 1991. The spectrum of responsibility. New York: St. Martin's Press.

French, P.A. (ed.). 1998. Individual and collective responsibility, 2nd ed. Rochester: Shenkman Books.

Gallouj, F., and O. Weinstein. 1997. Innovation in services. Research Policy 26(4): 537-556.

Gilbert, N. 2008. Agent-based models. Thousand Oaks: Sage.

Gilbert, N., and J. Doran (eds.). 1994. Simulating societies: The computer simulation of social phenomena. London: UCL Press.

Gilbert, N., and P. Terna. 2000. How to build and use agent-based models in social science. Mind \& Society 1(1): $57-72$.

Godin, B., and J.P. Lane. 2013. Pushes and pulls: Hi(S)tory of the demand pull model of innovation. Science, Technology \& Human Values 38(5): 621-654.

Graupe, S. 2012. The power of ideas. The teaching of economics and its image of man. JSSE - Journal of Social Science Education 11(2): 60-85.

Greene, B. 2004. The fabric of the cosmos: Space, time, and the texture of reality. New York: Random House.

Grinbaum, A., and C. Groves. 2013. What is "responsible" about responsible innovation? Understanding the ethical issues. In Responsible innovation: Managing the responsible emergence of science and innovation in society, ed. R. Owen, J. Bessant, and M. Heintz, 119-142. Chichester: Wiley.

Guerzoni, M. 2010. The impact of market size and users' sophistication on innovation: The patterns of demand. Economics of Innovation and New Technology 19(1): 113-126.

Güth, W., R. Schmittberger, and B. Schwarze. 1982. An experimental analysis of ultimatum bargaining. Journal of Economic Behavior \& Organization 3(4): 367-388.

Hall, B.H., and N. Rosenberg (eds.). 2010. Handbook of the economics of innovation (Vol. 1 \& Vol. 2). Amsterdam: North-Holland.

Hamill, L., and N. Gilbert. 2016. Agent-based modelling in economics. Chichester: Wiley.

Hamming, R.W. 1950. Error detecting and error correcting codes. Bell Labs Technical Journal 29(2): 147-160.

Hanusch, H., and A. Pyka (eds.). 2007a. Elgar companion to neo-Schumpeterian economics. Cheltenham: Edward Elgar.

Hanusch, H., and A. Pyka. 2007b. A roadmap to comprehensive neo-Schumpeterian economics. In Elgar Companion to neo-Schumpeterian economics, ed. H. Hanusch and A. Pyka, 1160-1170. Cheltenham: Edward Elgar.

Hanusch, H., and A. Pyka. 2007c. Applying a comprehensive neo-Schumpeterian approach to Europe and its Lisbon Agenda. In 50 years of EU economic dynamics: Integration, financial markets and innovations, ed. R. Tilly, P.J.J. Welfens, and M. Heise, 275-299. Heidelberg: Springer.

Harsanyi, J. C. 1980. Essays on ethics, social behavior, and scientific explanation (Vol. 12 Theory and Decision Library). Dordrecht: Reidel.

Heidbrink, L., and A. Hirsch (eds.). 2008. Verantwortung als marktwirtschaftliches Prinzip: Zum Verhältnis von Moral und Ökonomie. Frankfurt am Main: Campus.

Heidbrink, L., and I. Schmidt. 2011a. Das Prinzip der Konsumentenverantwortung - Grundlagen, Bedingungen und Umsetzungen verantwortlichen Konsums. In Die Verantwortung des Konsumenten. Über das Verhältnis von Markt, Moral und Konsum, ed. L. Heidbrink, I. Schmidt, and B. Ahaus, 25-56. Frankfurt am Main: Campus.

Heidbrink, L., and I. Schmidt. 2011b. Konsumenten als verantwortliche Marktakteure. In Fallstudien zur Ethik in Wissenschaft, Wirtschaft, Technik und Gesellschaft. Schriftenreihe des Zentrums für Technik- und Wirtschaftsethik, vol. 4, ed. M. Maring, 96-104. Karlsruhe: KIT Scientific Publishing.

Heidbrink, L., and I. Schmidt. 2011c. Mehr Verantwortung für den Konsumenten. Ökologisches Wirtschaften 26(3): 35-38.

Henning, C. 2015. Gibt es eine Pflicht zur Übernahme der geteilten Verantwortung? Über Komplikationen im Anschluss an Iris Marion Young. Zeitschrift für Praktische Philosophie 2(2): 61-86.

Herrmann-Pillath, C. 2013. Foundations of economic evolution: A treatise on the natural philosophy of economics. Cheltenham: Edward Elgar. 
Heukelom, F. 2014. Behavioral economics: A history. Cambridge: Cambridge University Press.

Hodgson, G.M. 1998. Evolutionary and competence-based theories of the firm. Journal of Economic Studies 25(1): 25-56.

Hodgson, G.M. 2011. A philosophical perspective on contemporary evolutionary economics. In The Elgar companion to recent economic methodology, ed. J.B. Davis and D.W. Hands, 299-318. Cheltenham: Edward Elgar.

Hodgson, G.M., and T. Knudsen. 2010. Darwin's conjecture: In search for general principles of social and economic evolution. Chicago: The University of Chicago Press.

Hühn, M.P., and C. Dierksmeier. 2016. Will the real A. Smith please stand up! Journal of Business Ethics 136(1): $119-132$.

Iatridis, K., and D. Schroeder. 2016. Responsible research and innovation in industry: The case for corporate responsibility tools. Cham: Springer.

Jensen, M.C., and W.H. Meckling. 1976. Theory of the firm: Managerial behavior, agency costs and ownership structure. Journal of Financial Economics 3(4): 305-360.

Jevons, W.S. 1871/1957. The theory of political economy (1965 reprinted 5th ed.). New York: Sentry Press.

Jevons, W.S. 1981. Papers on political economy. In Papers and correspondence of William Stanley Jevons, vol. VII, ed. R.D. Black. London: Macmillan.

Jonas, H. 1984. The imperative of responsibility: In search of an ethics for the technological age. Chicago: The University of Chicago Press.

Kahneman, D. 2011. Thinking, fast and slow. New York: Farrar, Straus \& Giroux.

Kant, I. 1785/2011. Groundwork of the metaphysics of morals (A German-English edition, ed. and transl. by M. Gregor and J. Timmermann). Cambridge: Cambridge University Press.

Kant, I. 1788/2002. Critique of practical reason. (trans. W.S. Pluhar). Cambridge, MA: Hackett Publishing.

Keen, S. 2011. Debunking economics - revised and expanded edition: The naked emperor dethroned? London: Zed Books.

Kiesling, E., M. Günther, C. Stummer, and L.M. Wakolbinger. 2012. Agent-based simulation of innovation diffusion: A review. Central European Journal of Operations Research 20(2): 183-230.

Klein, E.E., and P.J. Herskovitz. 2005. Philosophical foundations of computer simulation validation. Simulation \& Gaming 36(3): 303-329.

Kleindorfer, G.B., L. O’Neill, and R. Ganeshan. 1998. Validation in simulation: Various positions in the philosophy of science. Management Science 44(8): 1087-1099.

Kline, S.J. 1985. Innovation is not a linear process. Research Management 28(4): 36-45.

Kline, S.J., and N. Rosenberg. 1986. An overview of innovation. In The positive sum strategy: Harnessing technology for economic growth, ed. R. Landau and N. Rosenberg, 275-305. Washington, D.C.: National Academy Press.

Koops, B.-J. 2015. The concepts, approaches, and applications of responsible innovation: An introduction. In Responsible innovation 2: Concepts, approaches, and applications, ed. B.-J. Koops, I. Oosterlaken, H. Romijn, T. Swierstra, and J. van den Hoven, 1-15. Cham: Springer.

Kudic, M. 2015. Innovation networks in the German laser industry: Evolutionary change, strategic positioning, and firm innovativeness. Cham: Springer.

Kutz, C. 2000. Complicity: Ethics and law for a collective age. Cambridge: Cambridge University Press.

Lancaster, K. 1966. A new approach to consumer theory. The Journal of Political Economy 74(2): 132157.

Lancaster, K. 1975. Socially optimal product differentiation. The American Economic Review 65(4): $567-585$.

Lancaster, K. 1979. Variety, equity, and efficiency: Product variety in an industrial society. New York: Columbia University Press.

Lange, A. 2012. Darwins Erbe im Umbau: Die Säulen der Erweiterten Synthese in der Evolutionstheorie. Würzburg: Königshausen \& Neumann.

Lavoie, M. 2014. Post-Keynesian economics: New foundations. Cheltenham: Edward Elgar.

Lusch, R.F., and S.L. Vargo. 2006. Service-dominant logic: Reactions, reflections and refinements. Marketing Theory 6(3): 281-288.

Macal, C.M., and M.J. North. 2005. Tutorial on agent-based modeling and simulation. In Proceedings of the 2005 Winter Simulation Conference, ed. M.E. Kuhl, N.M. Steiger, F.B. Armstrong, and J.A. Joines, 2-15. New York: Winter Simulation Conference Board of Directors.

Macal, C.M., and M.J. North. 2006. Tutorial on agent-based modeling and simulation part 2: How to model with agents. In Proceedings of the 2006 Winter Simulation Conference, ed. L.F. Perrone, B.G. Lawson, J. Liu, and F.P. Wieland, 73-83. Monterey: Omnipress.

Macal, C.M., and M.J. North. 2010. Tutorial on agent-based modelling and simulation. Journal of Simulation 4: $151-162$. 
Macal, C.M., and M.J. North. 2014. Introductory tutorial: Agent-based modeling and simulation. In Proceedings of the 2014 Winter Simulation Conference, ed. A. Tolk, S.Y. Diallo, I.O. Ryzhov, L. Yilmaz, and S.M. Buckley, 6-20. Savannah: Omnipress.

MacIntyre, A. 2007. After virtue: A study in moral theory, 3rd ed. Notre Dame: University of Notre Dame Press.

Macklin, R., K. Mathison, and M. Dibben. 2014. Process ethics and business: Applying process thought to enact critiques of mind/body dualism in organizations. Process Studies 43(2): 61-86.

Magnusson, L. (ed.). 1994. Evolutionary and neo-Schumpeterian approaches to economics. Dordrecht: Kluwer Academic Publishers.

May, L. 1992. Sharing responsibility. Chicago: The University of Chicago Press.

Mazzucato, M. 2013. The entrepreneurial state: Debunking public vs. private sector myths. London: Anthem Press.

Mazzucato, M. 2016. Innovation policy as creating markets, not only fixing them. In Complexity and evolution: Toward a new synthesis for economics, ed. D.S. Wilson and A. Kirman, 271-284. Cambridge: The MIT Press.

Moraes, C., D. Shaw, and M. Carrigan. 2011. Purchase power: An examination of consumption as voting. Journal of Marketing Management 27(9/10): 1059-1079.

Mueller, M., and A. Pyka. 2017. Economic behaviour and agent-based modelling. In Routledge handbook of behavioral economics, ed. R. Frantz, S.-H. Chen, K. Dopfer, F. Heukelom, and S. Mousavi, 405-415. Abingdon: Routledge.

Mueller, M., B. Schrempf, and A. Pyka. 2015. Simulating demand-side effects on innovation. International Journal of Computational Economics and Econometrics 5(3): 220-236.

Nagel, T. 2005. The problem of global justice. Philosophy \& Public Affairs 33(2): 113-147.

Namatame, A., and S.-H. Chen. 2016. Agent-based modeling and network dynamics. Oxford: Oxford University Press.

Nelson, R.R., and S.G. Winter. 1982. An evolutionary theory of economic change. Cambridge: The Belknap Press of Harvard University Press.

Newholm, T. 2005. Case studying ethical consumers' projects and strategies. In The ethical consumer, ed. R. Harrison, T. Newholm, and D. Shaw, 107-124. London: Sage.

Newman, M.E.J. 2010. Networks: An introduction. Oxford: Oxford University Press.

Nill, J. 2009. Ökologische Innovationspolitik. Eine evolutorisch-ökonomische Perspektive. Marburg: Metropolis.

Nill, J. 2011. Environmental innovation policy: The contribution of evolutionary economics to solve some puzzles of environmental economics. (Paper submitted for EAERE 2011).

Nill, J., and R. Kemp. 2009. Evolutionary approaches for sustainable innovation policies: From niche to paradigm? Research Policy 38(4): 668-680.

Owen, R., P. Macnaghten, and J. Stilgoe. 2012. Responsible research and innovation: From science in society to science for society, with society. Science and Public Policy 39: 751-760.

Owen, R., J. Stilgoe, P. Macnaghten, M. Gorman, E. Fisher, and D. Guston. 2013. A framework for responsible innovation. In Responsible innovation: Managing the responsible emergence of science and innovation in society, ed. R. Owen, J. Bessant, and M. Heintz, 27-50. Chichester: Wiley.

Page, S.E. 2011. Diversity and complexity. Princeton: Princeton University Press.

Paine, L.S. 2003. Value shift: Why companies must merge social and financial imperatives to achieve superior performance. New York: McGraw-Hill.

Pareto, V. 1971. Manual of political economy, Reprint ed. New York: Kelley.

Parks, R.B., P.C. Baker, L. Kiser, R. Oakerson, E. Ostrom, et al. 1981. Consumers as coproducers of public services: Some economic and institutional considerations. Policy Studies Journal 9(7): 1001-1011.

Pavie, X., and D. Carthy. 2014. Addressing the wicked problem of responsible innovation through design thinking. In Responsible innovation, ed. N. Buzás and M. Lukovics, 13-27. Szeged: University of Szeged, Faculty of Economics and Business Administration.

Pavie, X., and J. Egal. 2014. Innovation and responsibility: A managerial approach to the integration of responsibility in a disruptive innovation model. In Responsible innovation 1: Innovative solutions for global issues, ed. J. van den Hoven, N. Doorn, T. Swierstra, B.-J. Koops, and H. Romijn, 53-66. Dordrecht: Springer.

Pavie, X., V. Scholten, and D. Carthy. 2014. Responsible innovation: From concept to practice. Singapore: World Scientific.

Payne, A.F., K. Storbacka, and P. Frow. 2008. Managing the co-creation of value. Journal of the Academy of Marketing Science 36(1): 83-96.

Pellé, S., and B. Reber. 2013. Deliverable No. D 2.2 - Theoretical landscape. Retrieved from http://www.greatproject.eu/deliverables_files/deliverables03.

Penz, G.P. 1986. Consumer sovereignty and human interests. Cambridge: Cambridge University Press.

Persky, J. 1993. Retrospectives: Consumer sovereignty. The Journal of Economic Perspectives 7(1): 183-191. 
Plotkin, H.C. 1987. Evolutionary epistemology and the synthesis of biological and social science. In Evolutionary epistemology: A multiparadigm program, ed. W. Callebaut and R. Pinxten, 75-96. Dordrecht: Reidel/Kluwer.

Potts, J. 2017. Behavioral innovation economics. In Routledge handbook of behavioral economics, ed. R. Frantz, S.-H. Chen, K. Dopfer, F. Heukelom, and S. Mousavi, 392-404. Abingdon: Routledge.

Pyka, A. 2002. Innovation networks in economics: From the incentive-based to the knowledge-based approaches. European Journal of Innovation Management 5(3): 152-163.

Pyka, A. 2007. Innovation networks. In Elgar companion to neo-Schumpeterian economics, ed. H. Hanusch and A. Pyka, 360-376. Cheltenham: Edward Elgar.

Pyka, A. 2014. Avoiding evolutionary inefficiencies in innovation networks. Prometheus 32(3): 265-279.

Pyka, A., and G. Fagiolo. 2007. Agent-based modelling: A methodology for neo-Schumpeterian economics. In The Elgar companion to neo-Schumpeterian economics, ed. H. Hanusch and A. Pyka, 467-487. Cheltenham: Edward Elgar.

Pyka, A., and T. Grebel. 2006. Agent-based modelling - A methodology for the analysis of qualitative development processes. In Agent-based computational modelling, ed. F.C. Billari, T. Fent, A. Prskawetz, and J. Scheffran, 17-35. Heidelberg: Springer.

Pyka, A., and A. Scharnhorst (eds.). 2009. Innovation networks: New approaches in modelling and analyzing. Berlin: Springer.

Rawls, J. 1999. A theory of justice revised edition. Cambridge, MA: The Belknap Press of Harvard University Press.

Rittel, H.W.J., and M.M. Webber. 1973. Dilemmas in a general theory of planning. Policy Sciences 4(2): 155169.

Robert, V., and G. Yoguel. 2015. The ontology of complexity and the implications for innovation policy. In The economics of knowledge, innovation and systemic technology policy, ed. F. Crespi and F. Quatraro, 203-238. Abingdon: Routledge.

Robert, V., and G. Yoguel. 2016. Complexity paths in neo-Schumpeterian evolutionary economics, structural change and development policies. Structural Change and Economic Dynamics 38: 3-14.

Rogers, E.M. 2003. Diffusion of innovations, 5th ed. New York: Free Press.

Rutherford, D. 2007. Economics: The key concepts. New York: Routledge.

Saviotti, P.P. 1996. Technological evolution, variety, and the economy. Cheltenham: Edward Elgar.

Saviotti, P.P., and J.S. Metcalfe. 1984. A theoretical approach to the construction of technological output indicators. Research Policy 13(3): 141-151.

Saviotti, P.P., and A. Pyka. 2012. On the co-evolution of innovation and demand: Some policy implications. Revue de l'OFCE 5: 347-388.

Schilperoord, M., B. Schrempf, and M. Müller. 2015. Deliverable No. D 4.3 - Agent-based model prototype Technical report for the Governance of Responsible Innovation (GREAT) project. Retrieved from: http://www.great-project.eu/Deliverables08 .

Schlaile, M.P. 2015. Ökonomische Entwicklung oder Evolution? Normative Relevanz des teleologischen Fortschrittsdenkens und Drift sozioökonomischer Selektionseinheiten (short discussion paper). doi:10.13140/RG.2.1.3445.5204.

Schlaile, M.P., and M. Ehrenberger. 2016. Complexity, cultural evolution, and the discovery and creation of (social) entrepreneurial opportunities: Exploring a memetic approach. In Complexity in entrepreneurship, innovation and technology research, ed. E.S.C. Berger and A. Kuckertz, 63-92. Cham: Springer.

Schlaile, M.P., K. Klein, and W. Böck. 2016. From bounded morality to consumer social responsibility: A transdisciplinary approach to socially responsible consumption and its obstacles. Journal of Business Ethics. doi:10.1007/s10551-016-3096-8.

Schmidt, I. 2016. Consumer Social Responsibility: Gemeinsame Verantwortung für nachhaltiges Konsumieren und Produzieren. Wiesbaden: Springer.

Schramm, M. 2006. Moralische Interessen in der Unternehmensethik. In Wirtschaftsethische Perspektiven VIII: Grundsatzfragen, Unternehmensethik, Institutionen, Probleme internationaler Kooperation und nachhaltiger Entwicklung. Schriften des Vereins für Socialpolitik, 228/VIII, ed. U. Ebert, 13-39. Berlin: Duncker \& Humblot.

Schramm, M. 2008. Ökonomische Moralkulturen. Die Ethik differenter Interessen und der plurale Kapitalismus. Marburg: Metropolis.

Schramm, M. 2010. Differenziertes Anreizmanagement: Behavioral Law und Wirtschaftsethik. Jahrbuch für Recht und Ethik - Annual Review of Law and Ethics 18: 405-418.

Schramm, M. 2015. Die menschliche Natur "schubsen": Moralökonomisches Anreizmanagement in der Behavioral Business Ethics. In Wirtschaftsethische Perspektiven X: Wirtschaftsethik nach der Wirtschaftsund Finanzkrise. Schriften des Vereins für Socialpolitik, 228/X, ed. R. Neck, 95-128. Berlin: Duncker \& Humblot. 
Schramm, M. 2016. Wie funktioniert die Geschäftswelt wirklich? Business Metaphysics und Theorie der Firma. ETHICA Wissenschaft und Verantwortung 24(4): 311-360.

Schramm, M. 2017. How the (business) world really works. Business metaphysics \& "creating shared value". In Creating shared value - Concepts, experience, criticism, ed. J. Wieland, 81-117. Cham: Springer.

Schumpeter, J.A. 1943. Capitalism, socialism and democracy. London: Routledge.

Sen, A.K. 1977. Rational fools: A critique of the behavioral foundations of economic theory. Philosophy \& Public Affairs 6(4): 317-344.

Sen, A.K. 1999. Commodities and capabilities. Oxford: Oxford University Press / Oxford India Paperbacks.

Senge, P.M., and G. Carstedt. 2001. Innovating our way to the next industrial revolution. MIT Sloan Management Review 42(2): 24-38.

Shaw, D., T. Newholm, and R. Dickinson. 2006. Consumption as voting: An exploration of consumer empowerment. European Journal of Marketing 40(9/10): 1049-1067.

Simon, H.A. 1955. A behavioral model of rational choice. The Quarterly Journal of Economics 69(1): 99-118.

Simon, H.A. 1959. Theories of decision-making in economics and behavioral science. The American Economic Review 49(3): 253-283.

Simon, H.A. 1972. Theories of bounded rationality. In Decision and organization, ed. C.B. McGuire and R. Radner, 161-176. Amsterdam: North-Holland.

Simon, H.A. 1997. Models of bounded rationality, vol. 3: Empirically grounded economic reason. Cambridge: The MIT Press.

Smith, A. 1759/2009. The theory of moral sentiments (ed. R.P. Hanley). New York: Penguin.

Smith, A. 1776/1952. An inquiry into the nature and causes of the wealth of nations (Great Books of the Western World ed.). Chicago: Encyclopædia Britannica.

Soete, L. 2013. Is innovation always good? In Innovation studies: Evolution \& future challenges, ed. J. Fagerberg, B.R. Martin, and E.S. Andersen, 134-144. Oxford: Oxford University Press.

Stahl, B.C. 2013. Responsible research and innovation: The role of privacy in an emerging concept. Science and Public Policy 40(6): 708-716.

Stahl, B.C., G. Eden, and M. Jirotka. 2013. Responsible research and innovation in information and communication technology: Identifying and engaging with the ethical implications of ICTs. In Responsible innovation: Managing the responsible emergence of science and innovation in society, ed. R. Owen, J. Bessant, and M. Heintz, 199-218. Chichester: Wiley.

Stilgoe, J., R. Owen, and P. Macnaghten. 2013. Developing a framework for responsible innovation. Research Policy 42(9): 1568-1580.

Swann, G.M.P. 2009. The economics of innovation: An introduction. Cheltenham: Edward Elgar.

Tammelleo, S., and L.G. Lombardi. 2014. Consumer social responsibility? Business \& Professional Ethics Journal 33(1): 99-126.

Thaler, R.H., and C.R. Sunstein. 2008. Nudge: Improving decisions about health, wealth, and happiness. New Haven: Yale University Press.

Tubaro, P. 2011. Computational economics. In The Elgar companion to recent economic methodology, ed. J.B. Davis and D.W. Hands, 209-227. Cheltenham: Edward Elgar.

Valente, M. 2009. Markets for heterogeneous products: A boundedly rational consumer model. LEM Working Paper Series 2009/11. Retrieved from https://www.econstor.eu/dspace/bitstream/10419/89424 /1/640591833.pdf.

Valente, M. 2012. Evolutionary demand: A model for boundedly rational consumers. Journal of Evolutionary Economics 22(5): 1029-1080.

van Griethuysen, P. 2002a. La contribution de l'économie évolutive dans la problématique du développement durable. PhD thesis, University of Geneva (retrieved from: http://archive-ouverte.unige.ch/unige:17312).

van Griethuysen, P. 2002b. Sustainable development: An evolutionary economic approach. Sustainable Development 10(1): 1-11.

Vermeulen, B., and A. Pyka. 2016. Agent-based modeling for decision making in economics. Economics: The Open-Access, Open-Assessment E-Journal 10: 1-33.

Verspagen, B. 2005. Innovation and economic growth. In The Oxford handbook of innovation, ed. J. Fagerberg, D.C. Mowery, and R.R. Nelson, 487-513. Oxford: Oxford University Press.

Vitell, S.J. 2003. Consumer ethics research: Review, synthesis and suggestions for the future. Journal of Business Ethics 43(1-2): 33-47.

Vitell, S.J. 2015. A case for consumer social responsibility (CnSR): Including a selected review of consumer ethics/social responsibility research. Journal of Business Ethics 130(4): 767-774.

von Hippel, E. 1986. Lead users: A source of novel product concepts. Management Science 32(7): 791-805.

von Hippel, E. 2005. Democratizing innovation: The evolving phenomenon of user innovation. Journal für Betriebswirtschaft 55(1): 63-78. 
von Hippel, E., S. Ogawa, and J.P.J. De Jong. 2011. The age of the consumer-innovator. MIT Sloan Management Review 53(1): 27-35.

von Mises, L. 1998. Human action: A treatise on economics (The Scholar's ed.). Auburn: Bettina Bien Greaves / The Ludwig von Mises Institute.

von Schomberg, R. 2013. A vision of responsible research and innovation. In Responsible innovation: Managing the responsible emergence of science and innovation in society, ed. R. Owen, J. Bessant, and M. Heintz, 5174. Chichester: Wiley.

Walras, L. 1874. Elements of pure economics or the theory of social wealth, 1969 ed. Cranbury: Scholar's Bookshelf.

Wasserman, S., and K. Faust. 1994. Social network analysis: Methods and applications. Cambridge: Cambridge University Press.

Whitehead, A.N. 1929/1978. Process and reality: An essay in cosmology (ed. D.R. Griffin and D.W. Sherburne, corrected ed.). New York: Free Press.

Whitehead, A. N. 1933/1967. Adventures of ideas. New York: Free Press.

Wilensky, U., and W. Rand. 2015. An introduction to agent-based modeling: Modeling natural, social, and engineered complex systems with NetLogo. Cambridge: The MIT Press.

Wilson, D.S., and A. Kirman (eds.). 2016. Complexity and evolution: Toward a new synthesis for economics. Cambridge: The MIT Press.

Winsberg, E. 2009. Computer simulation and the philosophy of science. Philosophy Compass 4(5): 835-845.

Witt, U. (ed.). 2001a. Escaping satiation: The demand side of economic growth. Berlin: Springer.

Witt, U. 2001b. Learning to consume - A theory of wants and the growth of demand. Journal of Evolutionary Economics 11(1): 23-36.

Witt, U. 2003. The evolving economy: Essays on the evolutionary approach to economics. Cheltenham: Edward Elgar. Witt, U. 2008. What is specific about evolutionary economics? Journal of Evolutionary Economics 18(5): 547-575.

Witt, U. 2014. The future of evolutionary economics: Why the modalities of explanation matter. Journal of Institutional Economics 10(4): 645-664.

Young, I.M. 2006. Responsibility and global justice: A social connection model. Social Philosophy and Policy 23(1): 102-130.

Young, I.M. 2007. Global challenges: War, self-determination and responsibility. Oxford: Oxford University Press.

Young, I.M. 2011. Responsibility for justice. Oxford: Oxford University Press.

Michael P. Schlaile is a research associate, teaching assistant, and doctoral student at the University of Hohenheim in Stuttgart. After completing his MSc (at the University of Hohenheim) in International Business and Economics in 2012, he decided to delve deeper into various topics such as the interplay of morality, cultural evolution, and economic processes and agents in complex systems. During his stay at the Danish Aalborg University, he developed a keen interest in evolutionary economics, entrepreneurship, and innovation studies. Michael Schlaile further holds the German degree Diplom-Betriebswirt (DH) in Banking from BadenWürttemberg Cooperative State University. His pre-academia work experience includes forex trading and consulting at a local bank's foreign trade department (KSK Waiblingen). From 2012 until the end of 2016, Michael Schlaile was part of the scientific staff at the Department of Catholic Theology and Business Ethics, where he worked for Prof. Dr. Michael Schramm as a research associate, teaching assistant, and doctoral student. In November 2016, he joined the staff of Prof. Dr. Andreas Pyka's Department of Innovation Economics. For more information, please visit https://inno.uni-hohenheim.de/en/schlaileen or follow him on ResearchGate (https://www.researchgate.net/profile/Michael_Schlaile).

Matthias Mueller is a postdoctoral research fellow at the University of Hohenheim, Stuttgart. He holds a diploma degree in economics from the University of Bremen. His main fields of research are neo-Schumpeterian and Evolutionary Economics. In his PhD he investigated the role of the demand side and its effects on innovation processes with the help of agent-based simulation environments. Further interests include innovation networks and social network analysis. For more information, please follow Matthias Mueller on ResearchGate (https://www.researchgate.net/profile/Matthias_Mueller28).

Michael Schramm is professor of Catholic theology and business ethics at the Faculty of Business, Economics and Social Sciences at the University of Hohenheim since 2001. Prior to this, he held the chair of Christian social sciences at the Faculty of Catholic Theology in Erfurt (1995-2001). He was speaker of the Association for Social Ethics (2006-2009) and is a member of the German Economic Association and the German Whitehead Society. His main research topics include business metaphysics, transaction ethics, process theology, and the metaphysics of money. See also https://theology-ethics.uni-hohenheim.de/88660 for more information on Michael Schramm. 
Andreas Pyka graduated in Economics and Management at the University of Augsburg in 1998. Thereafter, he spent two years as a postdoctoral researcher at the French National Institute for Agricultural Research in Grenoble, France. From 2002 until 2003 he held a guest professorship at the Austrian Research Centers "System Research" in Vienna and habilitated in 2004. Two years later he joined the University of Bremen where he became a professor for Economic Theory. In 2009 he was appointed to a professorship at the University of Hohenheim, Stuttgart where he has held the chair for innovation economics since April 2009. Please visit https://inno.uni-hohenheim.de/en/pykaen or follow Andreas Pyka on ResearchGate (https://www.researchgate. net/profile/Andreas_Pyka) for more information. 